\title{
Rituaalse aasta kajastumine vanasõnades: üldisi tähelepanekuid ${ }^{1}$
}

\begin{abstract}
Irina Sedakova
Teesid: Artiklis vaadeldakse rahvatarkuse väljendusi, mis seostuvad aja, selle kalendriliselt struktureeritud süsteemi ja teatud kuupäevadel läbi viidavate rituaalidega. Aastaringiga seoses on välja kujunenud vanasõnade süsteem. Vanad paganlikud aastaringi liigendamise printsiibid integreeriti kristlikku kirikukalendrisse ja nende põimumisel tekkis keerukas struktuur. Slaavi maades on see unikaalne kombinatsioon säilinud maapiirkondades, avaldudes rituaalsete tegevuste tõlgendamise ja kombestiku osas vormilt kristliku, kuid sisult paganlikuna. Rahvakalendri kromonüümid, milles tähtpäevade ja pühakute nimed on kohandunud traditsioonilise maailmavaatega, lahknevad religioossest terminoloogiast. Igal traditsioonil on etniline spetsiifika. Antud kontekstis on eriti olulised just keelelised erinevused. Ka kultuurilised ja geograafilised erinevused lisavad vanasõnadele oma varjundi. Iga Euroopa kultuur on välja arendanud viisi rituaalse aasta kajastamiseks vanasõnades, idioomides ja ütlustes. Iga ütlustetraditsiooni puhul võivad käsitletavad pühad ja tähtpäevad olla erinevad, kuid nendele ja kalendrirituaalidele viitamisel kehtivad vanasõnades universaalsed võtted.
\end{abstract}

Märksõnad: kalendaarsed ennustused, rahvakalender, rituaalne aasta, vanasõnad, õigeusu kalender

Käesolevas artiklis vaadeldakse rahvatarkuse väljendusi, mis seostuvad aja, selle kalendriliselt struktureeritud süsteemi ja teatud kuupäevadel läbi viidavate rituaalidega. Aastaringiga seoses on välja kujunenud vanasõnade süsteem, ${ }^{2}$ milles leidub viiteid peaaegu iga kalendripäeva kohta ja mis hõlmab suure üksikasjalikkusega kõiki inimese ja loodusega seonduvaid protsesse. Need folkloori lühižanrid on väga avar uurimisvaldkond. Küsimuse, kas saame üldse rääkida etnilisest paröömiast, esitas juba mainekas folklorist Dan Ben-Amos (1969) ning see on pakkunud huvi ka teistele teadlastele, olles jätkuvalt ülimalt aktuaalne, eriti seoses kõnekäändudega. Järgnevas keskendun eelkõige küsimusele, mis on traditsioonis universaalne ja mis unikaalne. 
Et käesolevas artiklis vaadeldakse rituaalset aastat puudutavaid ütlusi, on asjakohane anda esmalt lühike ülevaade rahvapärase ajakäsitluse iseloomulikest joontest nii, nagu need peegelduvad rahvakalendris. On üldteada, et vanad paganlikud aastaringi liigendamise printsiibid integreeriti kristlikku kirikukalendrisse ja nende põimumisel tekkis keerukas struktuur. Slaavi maades on see unikaalne kombinatsioon säilinud maapiirkondades ja väiksemates linnades, avaldudes rituaalsete tegevuste tõlgendamise ja kombestiku osas vormilt kristliku, kuid sisult paganlikuna (Tolstaja 2005, 9-10). Lisaks sellele on iga traditsioonilise kalendri puhul välja kujunenud rahvapärased krononüümid ehk tähtpäevanimed, millesse on kätketud mh ka nendele päevadele langevad pühade ja paastuperioodide nimetused ja vastavatel kuupäevadel austatavate pühakute nimed. Rahvakalendri terminoloogia, mis kohandas tähtpäevade ja pühakute nimesid traditsioonilise maailmavaatega, lahkneb tublisti religioossest terminoloogiast. Seega on igal traditsioonil ka siis, kui see on levinud vaid mõne suurema pärimusala raamesse jääval kitsal territooriumil, etniline spetsiifika - asjaolu, mis on hästi teada nii etnoloogidele kui ka folkloristidele. Antud kontekstis on eriti olulised just keelelised (murdelised) erinevused - need määravad rahvaetümoloogia kujunemise suunad, peegeldades ja rekonstrueerides seega rituaalide ja folkloori tähtsamaid etnilisi omapärasid. Ka kultuurilised ja geograafilised erinevused lisavad igasuguse pärimuse, sh vanasõnade unikaalsele iseloomule oma varjundi.

Vaatamata teatud erinevustele, mida rituaalse aasta rahvuslikes versioonides võib täheldada, on siiski mõningaid seiku, mis neid ühendavad ja on aluseks universaalsete arusaamade kujunemisele, nagu kuu ja päikesega seotud tsüklid, maaviljelus, karjakasvatus, lindude, putukate, loomade elu jm aastaaegadega seonduv. Kõik need asjaolud mõjutavad rahvapärast ajakäsitlust, kajastudes igas kalendrisüsteemis ja vastavalt ka vanasõnades.

Vanasõnades peegeldub rituaalne aasta tähtpäevanimetuste ja rituaalsete objektide, toitude ja toimuvast osavõtjate nimetamise kaudu, aga ka vihjetes aasta jooksul korraldatavatele pidustustele. Vanasõnad võivad kanda otseseid tähendusi, mis kehtivad ainult ühe konkreetse olukorra kohta, kuid nad võivad olla ka metafoorsed ja kehtida teatava situatsioonide kogumi kohta.

Otsese tähendusega vanasõnu ja kõnekäände leidub kõikides traditsioonides rohkelt. Nende olulisemateks teemadeks on ilm ja aastaaegade vaheldumine (rahvameteoroloogia), päikese asend taevas (rahvaastronoomia), elu looduses, põllutööd, karjaskäimine, jaht ja mesindus, sotsiaalne elu ning vahel ka rituaalne kalendrikombestik (viimane on tüüpilisem metafoorsetes vanasõnades). Need ütlused märgivad rituaalset aasta algust ja lõppu ning väljendavad looduslike sündmuste tsüklilist olemust ja korduvust mõningate kuupäevade või perioodide seostamise või vastandamise kaudu. Konkreetne täht- 


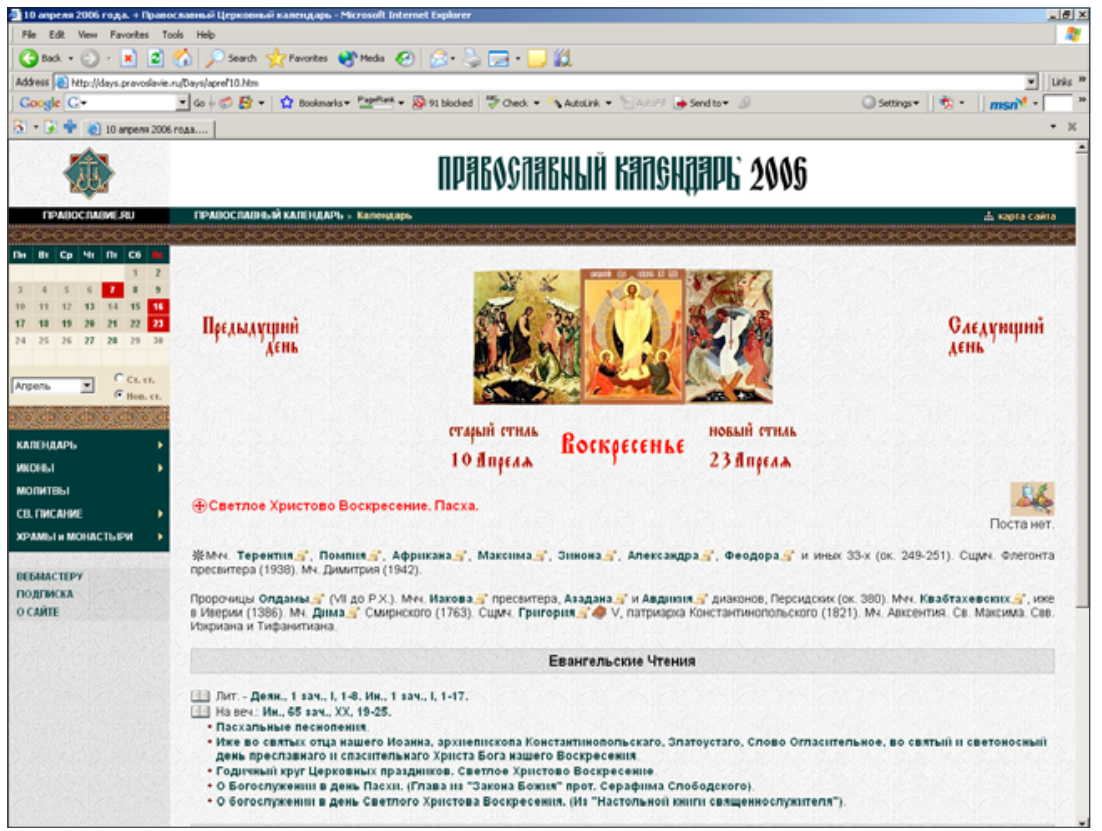

Foto 1. Vene kirikukalendri ja rahvakalendri põimumine on tekitanud keeruka ajaarvamissüsteemi. Üht varianti kirikukalendrist võib lugeda veebist aadressil http://days.pravoslavie.ru.

päev on piiritähis: mis on hea (soovitav) enne seda päeva ja mis on halb (keelatud) pärast seda (Venemaalt on näiteks üles kirjutatud ütlus: До Ильи лужик куnается, а с Ильи с рекой прощается 'Kuni eelijapäevani ${ }^{3}$ (20. juuli / 2. august) käib mees jões ujumas, aga pärast eelijapäeva jätab jõega hüvasti’; ДIo Ильи дождь - в закроли, после Ильи - из закрола 'Sajab enne eelijapäeva sajab salve [see on viljale hea], sajab pärast eelijapäeva, sajab salvest välja' (Korinfski 1994 (1901): 259, 261)). On ka ütlusi, mis kirjeldavad seda, mis juhtub enne ja pärast mingit konkreetset tähtpäeva, näiteks Polesjest ${ }^{4}$ on üles tähendatud vanasõna Кукушка до Пятра куе, а после Пятра курей дяре 'Enne peetripäeva $^{5}$ (29. juuni / 12. juuli) kägu kukub, aga pärast peetripäeva sööb kanapoegi'6 (Tolstaja 2005: 172). Mõningates vanasõnades seostatakse tähtpäevi sellega, mida tohib või ei tohi antud päeval teha (Polesjes näiteks $H a$ блавyсmy сей kanycmy 'blagusta päeval [paastumaarja- ehk kapsamaarjapäevale, ${ }^{7}$ (25. märts / 7. aprill) järgnev päev] külva kapsast') või mingi igal aastal korduva nähtusega (Polesjes öeldakse Михайло - снегу на.лахалю 'Mihkel (Mihailo $^{8}$ (8./21. november) võidab lume enda poole' (Tolstaja 2005: 38, 148); vene ütlus on ІІридёт Овдошка, и откроел окошко 'Tuleb Jevdokia ${ }^{9}$ (1./14. märts) ja avame akna' (Vostrikov 2000: 75)). Vanasõnades peegelduvad ka ühiskondlikud (või noorte) inimeste suhted (ukrainlased ütlevad ,До Д,литра dibka хит- 
ра, а по Дличтрі лавку нею витри 'Dimitripäevani ${ }^{10}$ (26. oktoober / 8. november) on tüdruk ahvatlev, aga pärast dimitripäeva ei kõlba ta enam kuhugi' [tüdruk kositakse enne dimitripäeva, pärast seda on kosjaskäimise aeg läbi]' (Polištšuk \& Ponomarjov 2000: 396)).

Iga ütlus õpetab omal viisil. Olemuslikult on need folkloorsed lühivormid keelud ja piirangud, nõuanded ja soovitused, märgid ja sümbolid, ettekuulutused, tingivad ennustused (kui ma teen X, siis juhtub Y) või lihtsalt väited. Ka sellel puhul võib mõni tähtpäev olla teatud tegevuse suhtes oluliseks piiritähiseks (Ukrainas öeldi На Глеба и Бориса за хлеб не берися 'Borisi- ja glebipäeval $^{11}$ ära leiba (st vilja) puutu' (Snegirev 1999: 406); vene tekst Kmo ceem рожь на Фролоһ день, у того родятся флорки 'Kes külvab rukist frolipäeval ${ }^{12}$ (18./31. august), selle [põld] kannab vaid õisi (st see jääb saagita)') (Snegirev 1999: 146).

Nagu juba öeldud, on rahvakalendriga seostuvate ütluste kasutamine ajaliselt piiratud - need esinevad ainult teatud tähtpäeva või püha kontekstis ja neid kasutatakse automaatselt ühe osana antud päevaga seonduvatest uskumustest. Samuti piirdub nende kasutamine kindla kohaga - enamasti on tegemist piirkondlike, murdekeelsete ütlustega (nende grammatika ja sõnavara ei vasta standardkeele reeglitele), mis seonduvad kindla piirkonna kliimaga. Seega on oluline nende ütluste geograafia, eriti nii suurel alal nagu Venemaal. Kui võrdleme näiteks ütluste põhjal maa põhja- ja lõunaosas käibivat rahvameteoroloogiat, märkab suuri erinevusi ajalistes määratlustes ja suhtumistes vihmasse, põuasse, tuultesse jne.

Nende ütluste puhul on võimalik rääkida ka sotsiaalsest mõõtmest: enamasti puudutavad need põllundusega tegelevat maaelanikkonda. Nõukogude ajalgi järgisid maainimesed rahvatarkusi vaatamata ideoloogilisele survele ja prevaleerivale minevikueitamisele. Seevastu ei olnud sellised mõtteterad linnades ega massimeedias kuigivõrd kasutusel. Perestroikajärgsel ajal on olukord märkimisväärselt muutunud. Vene rahvakultuuri rekonstrueerimisest ja uusloomest on saanud uus ideoloogia (Sedakova 2001: 132-133). Päevast päeva pakuvad raadiojaamad, teleprogrammid, ajalehed ja ajakirjad "rahvapärast" teavet konkreetselt käesoleva päeva kohta rituaalse aasta kontekstis. ${ }^{13}$ Olles inimestele "koju kätte toodud", muutuvad vanasõnad kõigile teadaolevaks informatsiooniks, mille hulka kuuluvad rahvameteoroloogia, põllunduskalender, rituaalsed tegevused, ennustamine jne. Peaaegu kohustuslikuks on muutunud selliste ütluste mainimine ja viitamine kiriklikele või rahvakalendri tähtpäevadele televisiooni ilmateates. Viisteist aastat tagasi ei tarvitsenud nõukogude inimene teada, mis on paastumaarjapäev, kuid nüüd kordasid kõik inimesed, kellega ma 2005. aasta 7. aprillil ${ }^{14}$ rääkima juhtusin, sama meteoroloogilist ennustust: "Öeldakse, et selline, nagu on ilm paastumaarja- 


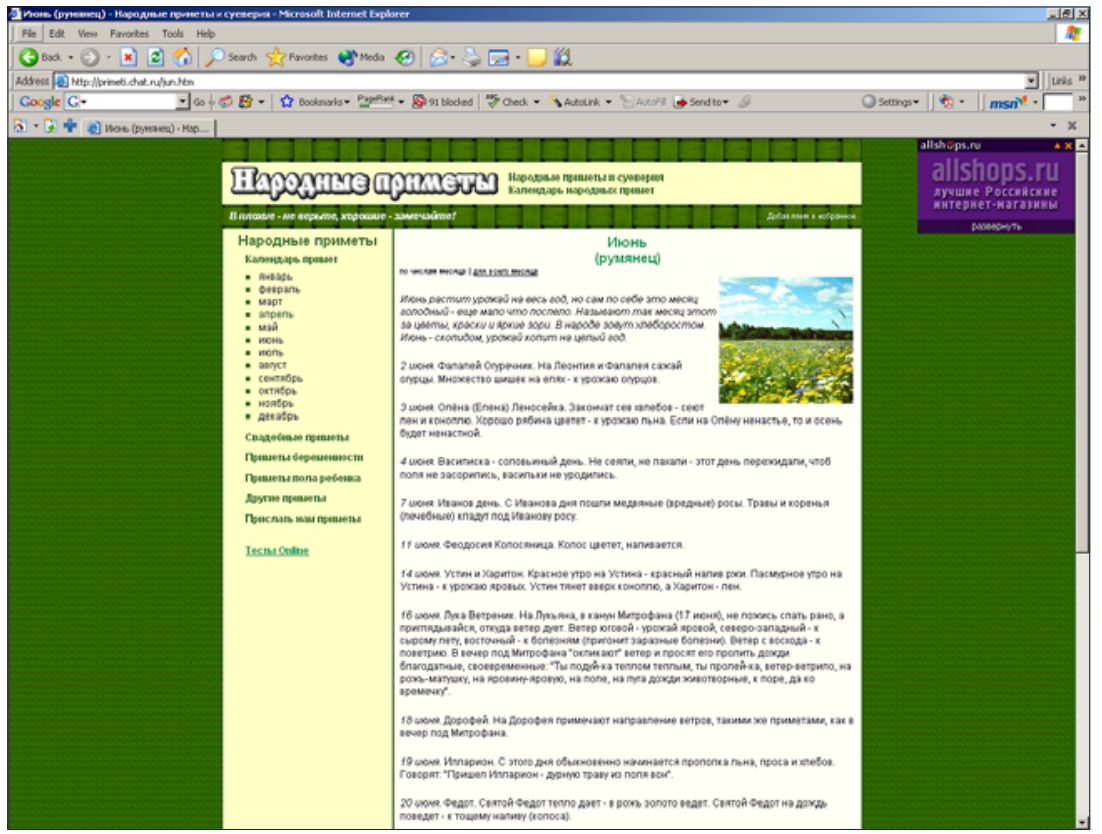

Foto 2. Üks vene rahvatarkusi jagavaid kalendreid "Narodnõje primetõ" (http:// primeti.chat.ru).

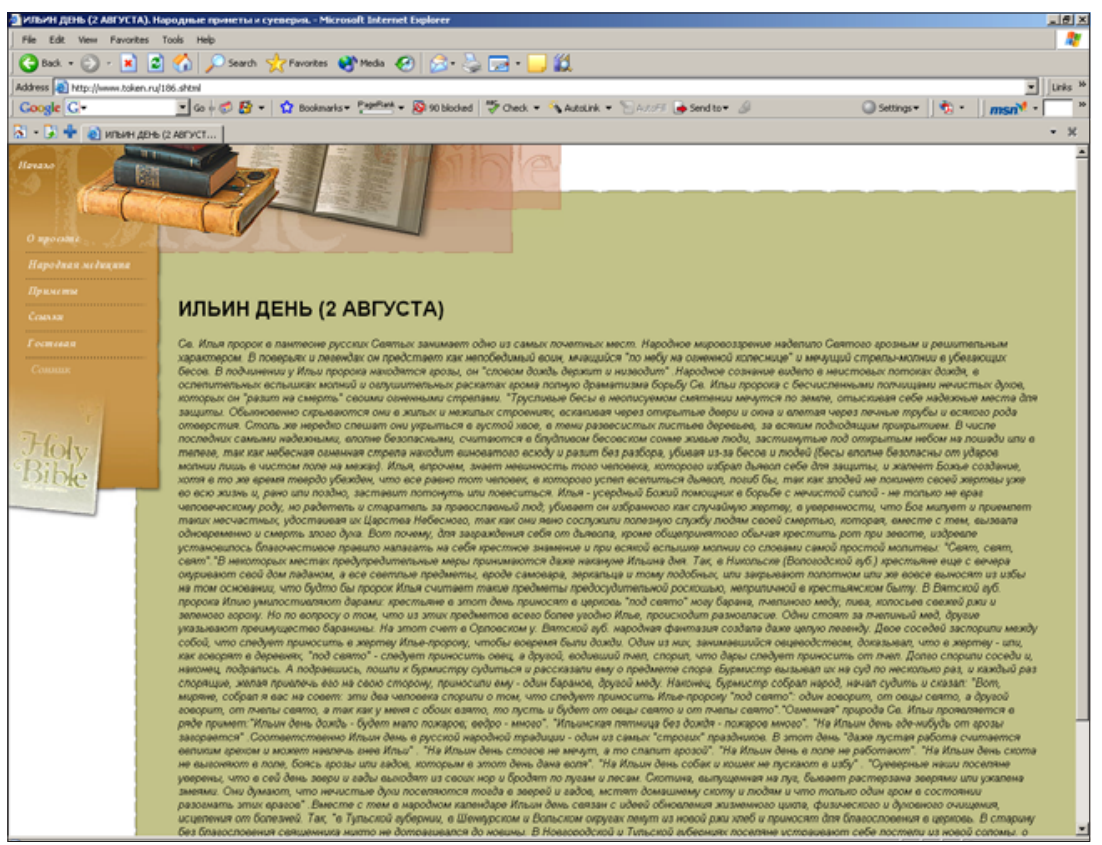

Foto 3. Leheküljel http://www.token ru on paljude muude rahvatarkuste kõrval kirjas ka kalendriended. 
päeval, on ta suvi läbi.” Et tean ka selle ütluse teist versiooni, laususin selle peale automaatselt: "Olgu paastumaarjapäev milline tahes, lihavõtted on samasugused." Ilmast rääkimine on igavene teema, kuid kirjeldatud "vanade uute" ütluste kasutamine niisuguses vestluses näitab uut arengut, osutades ilmekalt lühivormide sotsiaalsele olemusele.

Teine rühm praegusaja aktuaalseid ja populaarseid ütlusi on seotud rahvapärase põllunduskalendriga. Neid kasutatakse laiemas kontekstis kui pelgalt teleprogrammides ja maaviljelusega tegelevatele inimestele mõeldud väljaannetes (need inimesed järgivad maakodudes või suvilates peenraid tehes kirglikult kõike, mida vanarahvatarkus neil teha soovitab või keelab). Ükski inimene, kes loeb ajalehti ja ajakirju või kuulab raadiot, ei suuda hoiduda teadmast, milline vanasõnaline ütlus just käesoleva päeva kohta kehtib. Sageli jäävad need vanasõnad sisu poolest moskvalaste või teiste venelaste igapäevastest toimetustest vägagi kaugele - näiteks vana vene ütlus IІридет пророк Алос (15-е июня) - пойдет в рост и овес 'Kui tuleb prohvet Aamos' ${ }^{15}$ (15./ 28. juuni), hakkab kaer kasvama' (Korinfski 1994: 229) -, pealegi ei ole mainitud pühakunimed neile sageli üldse tuttavad. Nagu juba osutasin, on mulle jäänud mulje, et need ütlused on osalt üle võtnud sovjetlike ideoloogiliste loosungite koha, nagu reklaamgi.

Rahvaetümoloogial põhinevad kujundid ja poeetika, samuti vanasõnade keeleline ülesehitus pakuvad erilist huvi ütluste etnilisuse uurijale. Pühakute nimesid (mis olid slaavlastele võõrad, sest need on kreeka või heebrea päritolu (Tolstaja 2005: 377-384)), ja kirikupühade nimetusi (mis on kirikuslaavi-, mitte venekeelsed), on põhjalikult muudetud, et need assotsieeruksid venekeelsete sõnade või mõne rahvapärase nimetusega, millel on läbinähtav tähendus.

Pühakute ja pühade rahvapäraste nimetuste loendisse kuulub nende mitmeid erinevaid versioone ja epiteete, mis kirjeldavad pühade rahvapärast - mitte ortodoksse kiriku määratud - sisu ja vaimu. Seega võib ühel pühakunimel olla mitu erinevat versiooni, mis võimaldavad sõnu omavahel riimida (tüüpiline poeetiline vahend folkloori lühivormide, sh vanasõnade puhul). Polesjes teatakse Püha Jevdokial 16 lühikest nime, Püha Paraskeeval ${ }^{16}$ (28. oktoober /10. november) on kuus nimeversiooni ja Pühal Andreasel ${ }^{17}$ viis (Tolstaja 2005: 379-380). Võrdle näiteks järgnevaid riime: Кто напряде на Еудокы, то будут голь бокы 'Kes ketrab jevdokiapäeval, jääb paljaks (tal pole midagi selga panna)'; Евдоки с воры потоки 'Jevdokiapäeval (voolavad) ojad mäest alla', Еудокей - Воды по бокей 'Jevdokiapäeval on vesi vööni' (Tolstaja 2005: 95-96).

Väga oluline on kalendriliste vanasõnade puhul pühakunime (resp. tähtpäevanimetuse) rahvapärase semantika kasutamine ja selle seostamine looduses toimuvate muudatuste või põllutöödega. Ülimalt populaarsed on seo- 
sed, mis viitavad tegevusele, liikumisele, kohtumisele. Näiteks seostub venelaste сретение, встретение (stretenije, vstretenije, küünlapäev, ${ }^{18} 2 . / 15$. veebruar) sõnaga встреча (vstretša, 'kohtumine'), vt Polesjest pärit venekeelset näidet: На Сретенье зила с летол встречается 'Küünlapäeval kohtub talv suvega' (Korinfski 1994: 114; Vostrikov 2000: 74; Tolstaja 2005: 240).

Sõna Воздвиженье, Вздвиженье (ristiülendamise püha, ${ }^{19}$ 14./27. september) puhul kasutatakse sõnatüve двиг- (dvig-, 'liikuma, nihkuma') ilmaliku elu muudatuste kirjeldamiseks: На Воздииженье Солнце здвигается (m.е. игpaет, переливается всели иветали радуги) 'Ristiülendamise päeval vahetab päike värve (st päike mängib, veikleb kõigis vikerkaarevärvides); Ha дbope Воздбиженье, последняя копна с поля движется, последний воз нагулио тороnится 'Kui jõuab kätte ristiülendamise päev, liigub viimane rõuk põllult minema, viimane koorem kiirustab rehe alla'; На Вздвиженье ни зиея и никакой гад по зелле сырой не движется 'Ristiülendamise päeval ei liigu ükski madu ega muu roomaja maapinnal' (Korinfski 1994: 307); На Вздбиженье птица 6 отлет двинулась 'Ristiülendamise päeval hakkas (ränd-)lind liikuma' (Dal 1955: I, 226); Вздвиженье осень зиле навстречу двигает. Ristiülendamise päev nihutab sügise talvele vastu' (Korinfski 1994: 307) jne.

Mõnelgi teisel sügisesel kirikupühal on rahvapärases käsitluses samalaadne mõju aastaaegade vaheldumisele. Sõna Введенье (vvedenje, Neitsi Maarja templisseviimise püha, ${ }^{20} 21$. november / 4. detsember) tüvi вед (ved) tähendab 'kohale tooma, alustama': Введение приило - зилу на Русь завело 'Saabus leemetimaarjapäev ja tõi Venemaale talve' (Korinfski 1994: 374).

Sõna pokrov (suurmaarjapäev, Jumalaema kaitsmise päev, ${ }^{21} 1 . / 14$. oktoober) tüvi seostub mitmes slaavi keeles esineva tegusõnaga крыть (krõt, 'katma'), millele omistatakse ütlustes erinev tähendusvarjund. Venemaal öeldakse Покров зеллю покроет - где листол, а где и снежкол 'Pokrov katab maa kus lehtede ja kus lumega' (Korinfski 1994: 326), Polesjes Съвята Покрова, покрой зелельку листочколи, а головку веночкол 'Püha Pokrova, ${ }^{22}$ kata maa lehtede ja pea pulmavanikuga' (Tolstaja 2005: 348).

Rahvaetümoloogial põhinevad vanasõnad ei puuduta ainult kirikupühi, vaid ka pühakute mälestuspäevi. Püha Luuka ${ }^{23}$ nimi kõlab vene keeles nagu $л y k$ ('sibul'), Püha Helena ${ }^{24}$ (21. mai / 3. juuni) nimi - vene keeles Oлёнa (Aljona) sarnaneb sõnaga $\imath \ddot{e} u$ (ljon, 'lina'), Püha Makrina ${ }^{25}$ (Makrida, Mokrida; 19. juuli / 1. august) ja Püha Mokiuse ${ }^{26}$ (Mokei; 11./24. mai) nimed seostuvad vene rahvaetümoloogias sõnatüvega мокр- (mokr-, 'niiske, märg'): Мокро на Мокея (11-во лая) - Жди лета еще локрее 'Kui mokiusepäev on märg, on suvi veel märjem', nime Makabei (Makavei) ${ }^{27}$ seostatakse vene sõnaga мак (mak, 'mooniseemned'), Püha Korneeliuse ${ }^{28}$ (13./26. september $\left.{ }^{29}\right)$ nimi aga sõnaga корень (koren, 'juur'): Корнилий святой - из зелли корнеъище долой 'Korneeliusepäeval 
tõmmatakse kõik juured maast välja', С Корнилья корень $b$ зелле не растет, $a$ зябиет 'Pärast korneeliusepäeva juured maa sees enam ei kasva, sest külm teeb neile liiga' (Korinfski 1994: 297). Pühakute mälestuspäevad võidakse samal viisil siduda inimlike loomuomadustega, näiteks Püha Gordius ${ }^{30}$ (Gordei) seostub sõnatüvega горд- (gord-, 'uhkus'), või vaimsete võimetega, näiteks Püha Nahum ${ }^{31}$ (Naum; 1./14. detsember) seostub venekeelse sõnaga ум (um, 'aju, mõistus'): ІІророк Наул наставит на у.л'Püha Nahum juhatab mõistusele' (Korinfski 1994: 383) jne.

Võiks tuua veel palju näiteid samasuguste seoste kohta; see võte on tüüpiline paljudele rahvatraditsioonidele. Siinkohal toon välja mõned näited tähtpäevanimetustel põhinevate ütluste etnilise spetsiifika, sh ka rahvapärase etümoloogia kohta. Polesjes nimetatakse taevaminemispüha ${ }^{32}$ Вшестье ja Ушестье, mille tüves sisalduv sõna шесть (̌̌est, 'kuus') aitab inimestel meeles pidada, millal seda püha tuleb pühitseda - kuuendal nädalal pärast ülestõusmispühi (Tolstaja 2005: 59). Bulgaarias nimetatakse issandamuutmise püha ${ }^{33}$ (6./19. august) murdes Прибрижене, Приближене (Pribrižene, Približene) ${ }^{34}$ (Stojnev 1994: 284) - riimuva sõnatüve ближ (bliž, 'lähedal', 'lähenema') kaudu seostub see läheneva sügisega. Venelased selliseid seoseid taevaminemispüha ja issandamuutmise püha kohta ei tunne.

Vaatamata eeltoodule saab rääkida universaalsetest joontest vanasõnade seostamisel teatud päevadega. Nagu näha, on kõige enam päevi, mis seostuvad ilmamuutuse või aastaaja vahetumisega. Paastumaarjapäev on üks venelaste "lemmikpühi", mis märgib esimest tseremooniat kevade algust tähistavate rituaalide kogumis. Öeldakse, et paastumaarjapäeval ei tee isegi lind pesa (vrd üht versiooni vanasõnast: $3 a$ то кукушка без гнезда, что $b$ Блавовещенье его завила 'Käol ei ole pesa sellepärast, et ta ehitas selle paastumaarjapäeval' (Dal 1955: II, 214)). See uskumus avaldub paljudes vanasõnalistes ütlustes: $B$ kakoŭ день недели Благовещенъе, 6 тот, во весь год, никакого дела не начинать 'Sellel nädalapäeval, millele langeb paastumaarjapäev, ei alustata terve aasta jooksul ühegi tööga'; Коли весна ранее Благовещения станет, то много морозов впереди 'Kui kevad saabub enne paastumaarjapäeva, on ees veel palju pakaselisi päevi'; На Благовещенье мороз, урожай на овуриы 'Kui paastumaarjapäev on pakane, annavad kurgid head saaki'; Мокрое Благовещенье, грибиое лето 'Märg paastumaarjapäev toob seenerikka suve'; Гроза на Блавољещение к теплолу лету и к урожал орехов 'Paastumaarjapäeva äike toob sooja suve ja hea pähklisaagi'; Блавовещение без ласточек, холодная весна 'Pääsukesteta paastumaarjapäev tähendab külma külm kevadet'; Накануне Благовещения сеют горох 'Herneid tuleb külvata paastumaarja laupäeval' (Dal 1955: I, 91) jpt.

Paljudes ütlustes kajastub rahvapärane aasta liigendamine kaheks osaks nii, et moodustuvad paarid (Tšitšerov 1957; Propp 1963; Tolstoi 2002). Ena- 
masti mainitakse kaht tähtpäeva või kaht pühakut, kes seostuvad erinevatel ajalõikudel valitsevate ilmatikuoludega. Näiteks on olemas nii soe Aleksei (Aleksius) kui ka külm Aleksei, ${ }^{34}$ kevadine ja talvine nigulapäev ${ }^{35}$ (sama kehtib jüripäevade ${ }^{36}$ ja mitmete Ristija Johannesega ${ }^{37}$ seostuvate tähtpäevade kohta) jne. Venelastel oli kombeks öelda: На Руси - два Еворья, одии холоднигй, другой- голодньй 'Venemaal on kaks Jürit - üks on külm, teine - näljane', $\partial 6 a$ Николь: тепльй да холодный, сытьий да голодный'on kaks Nikolaid (Nigulat): soe ja külm, söönud ja näljane' (Korinfski 1994: 194). Vanasõnades esinevad mitte ainult ühesuguste nimedega pühakud (või ühe pühaku kaks mälestuspäeva), vaid ka erinevate pühakutega seostuvad üksteisele järgnevad tähtpäevad. Näiteks öeldakse, et kui y Ебдокеи бода, [siis] у Евория теплого (23-во апреля) mpaba' '[kui] jevdokiapäev [1./14. märts] on märg, [siis] jüripäeval (23. aprill / 6. mai]) on rohi väljas' (Korinfski 1994: 134); В осень Егорей с мостол, а Никола с звоздел 'Sügisel toob Jüri (26. november / 9. detsember) silla, aga Nigul (6./ 19. detsember) naela'; Еворий с водой, а Никола с травой 'Jüri (23. aprill) toob vee ja Nigul (9./23. mai) rohu' (Snegirev 1999: 73, 103). Üks laialt levinud ütlus käib kolme pühaku kohta, kelle mälestuspäevad on detsembris: vene ütlus Baрвара заварит, Савва засалит, Никола закуеm 'Barbara ${ }^{38}$ (4./17. detsember) keedab, Sabbas ${ }^{39}$ (5./18. detsember) lisab soola ja Nigul (6./19. detsember) paneb nahka' (Korinfski 1990: 385); Polesje ütlus Bapbара заварыть, а Микола потвердыть, а Ганки зобють санки... 'Barbara keedab ja Nigul külmetab kõvaks ja Anna ${ }^{40}$ (9./22. detsember) võtab kelgu kaasa...' (Tolstaja 2005: 42); serbia vanasõna Varvaritsa vari, a Savitsa hladi, Nikola kusa ${ }^{41}$ 'Barbara keedab, Sabbas külmutab ja Nigul sööb' (Ikonomov et al. 1968: 40) ning bulgaaria ütlus Варвара вари, Сава го соли, Никола яде 'Barbara keedab, Sabbas lisab soola, Nigul sööb' (Slavejkov 1972: 110). Siin võisime näha, kuidas pühakuid kujutatakse erinevates seostes (jälgige verbi varit kasutamist Barbara (Varvara) toimetuste kirjeldamisel, mis on võimalik slaavi keelte foneetilise sarnasuse tõttu). Vene ja Polesje ütlustes väljenduvad lume langemine ja talve algus, serbia ja bulgaaria omad aga keskenduvad rituaalsele toidule - nendeks päevadeks valmistatakse spetsiaalne roog panspermia,${ }^{42}$ ka mängib rolli kolme püha ajaline lähedus.

Ka Bulgaarias võib täheldada sümmeetrilisi pühakupäevi, näiteks talvine (18./31. jaanuar) ja suvine atanasiusepäev ${ }^{43}$ (5./18. juuli). Mõningates Bulgaaria ja Bessaraabia külades tuntud uskumuse järgi märgivad need pühad aasta teise poole algust, soojema või külmema perioodi saabumist (AA $<$ Bessaraabia, Kirsovo k - Irina Sedakova (1984)). Vene ütlustes atanasiusepäevadega seotud sümmeetriat ei ilmne. Kui jaanuarikuine atanasiusepäev märgib kõige külmemat perioodi, siis kevadine atanasiusepäev (2./15. mai) seostub külviaja algusega (Sedakova \& Tolstaja 1995: 119-21). 
Järgnevalt keskendun ühele kujundlike vanasõnade rühmale, mida saab kasutada olukordades, mis ei ole otseselt seotud ühegi konkreetse pühaku mälestuspäevaga. Niisuguseid ütlusi saab kasutada erinevatel puhkudel, mis ei tarvitse mainitava tähtpäevaga kronoloogiliselt seostuda (Permjakov 1970). Mitmed vanasõnad käivad suuremaid pidustusi sisaldavate kalendriliste rituaalide kohta. Samas puudutavad vanasõnades leiduvad viited jõuludele või ülestõusmispühale harva nende pühade religioosset tähendust, pigem mainitakse ainult suurt püha. Väga sageli tõuseb vanasõnades esile erilise, ebatavalise päeva tähendus. Konkreetse püha valik võib traditsiooniti olla erinev, nagu see ilmneb ka mõningate muidu samasuguse tähenduse ja struktuuriga balkani vanasõnade puhul. Bulgaarlased ütlevad Секи ден не е Великден 'Еga iga päev ole lihavõtted', Секи ден не биъо коледа 'Ega jõulusid saa iga päev pidada', türklased lausuvad Her gun bir bayram olmaz 'Bayrami ei saa iga päev pidada', rumeenlased sõnavad Odata-i craciunul intr-un an 'Jõulusid ei peeta iga päev' ja albaanlased kinnitavad Pashke s'eshte per dite 'Ega lihavõtted ole iga päev' (Ikonomov et al. 1968: 226). Vaatamata mainitud pühade erinevusele (ülestõusmispüha, jõulud, moslemi bayram) annavad eri kultuurid edasi ühte ja sama tõdemust (iga päev ei saa pidutseda), mis on kooskõlas normidega (vrd nendega vastandlikke bulgaaria ütlusi $3 a$ лудия всеки ден е празиик'Hullul on iga päev pühad'; За лудия ката ден е Великден 'Hullul on iga päev lihavõtted', st tegemist on normist põikuva olukorraga (Slavejkov 1972: 208)). Normi ja normist põikuva vastandamist esineb vanasõnades sageli, vrd näiteks vene ütlust Знает всяк, что Христов день праздник 'Igaüks saab aru, et lihavõtted on püha' (Snegirev 1999: 399).

Kalendripüha sümboliseerib lõbutsemist ja ohjeldamatut söömist. See seos kajastub paljudes vanasõnades, eriti aga nendes, mis viitavad võinädalale (paastueelsele ajale), nagu kinnitavad venelased: Масляница объедуха, деньвол подбируха 'Võinädal ${ }^{44}$ on õgard ja raharaiskaja' (Snegirev 1999: 158), Не житье, a ласленица 'See pole elu, vaid võinädal' (tähenduses 'tõeline pidupäev'), He bce коту масленица, будет и великий пост, не все в избытке жить 'Ega alati ole kassil võinädal, küll tuleb ka suur paast, ega kogu aeg külluses elata' (Dal 1955: II, 302). Ohjeldamatule joomisele võidakse viidata ka kahe ajaliselt lahus paikneva püha näitel: Іили на Масленице, с похлелья лолало на Радоницу 'Jõime võinädalal, aga pohmelus saabus alles pärast vanemate mälestuspäevaks $^{45}$ ' (Korinfski 1994: 124).

Seostamine mingi konkreetse kalendrikombega võib vahel luua semiootilise pretsedendi, millega viidatakse teatud tähtaja või ajalise piiri saabumisele. Mõned vanasõnad kirjeldavad seega küll pühade rituaalset sisu, ent rõhutavad sealjuures ka rituaalse käitumise põhimõtteid, õigete ja valede esemete kasutamist jne. Kohane või ebakohane käitumine võidakse asetada konk- 


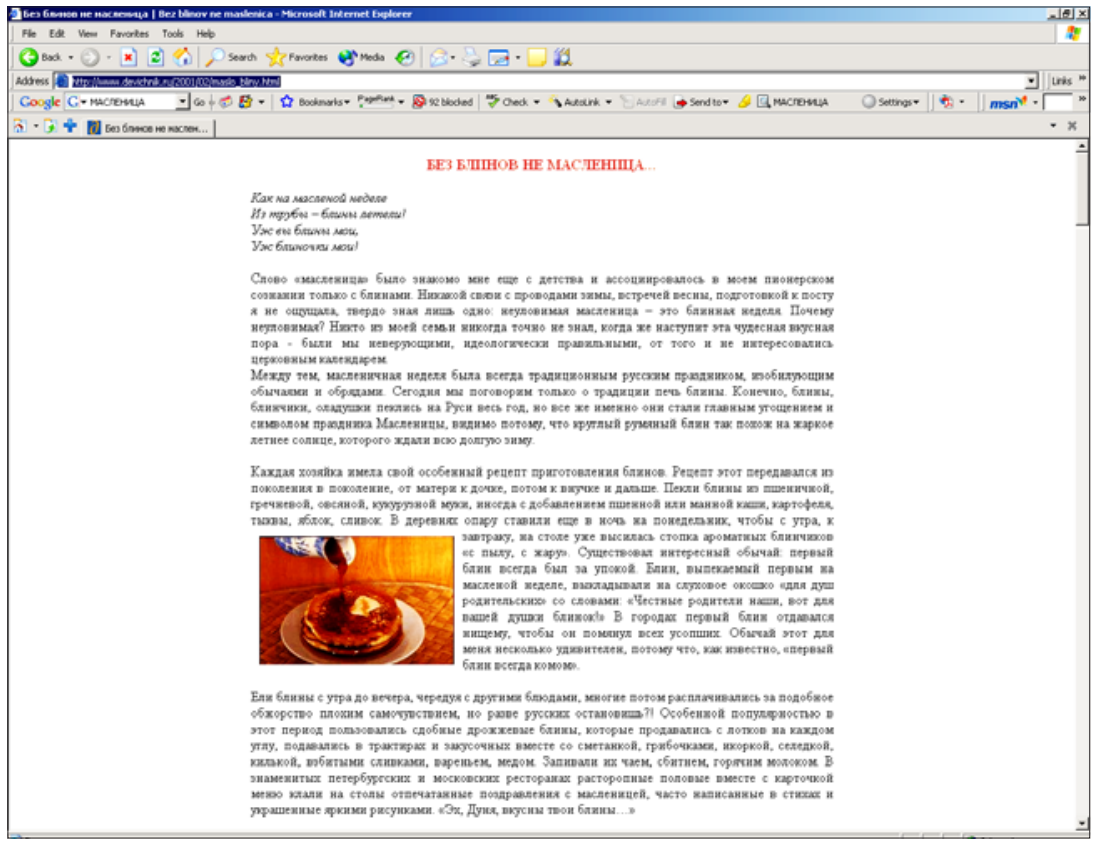

Foto 4. Kalendrivanasõnadega vürtsitatakse ka naisteajakirjade retseptikülgi, nagu näitab internetiajakiri Devitšnik.ru 2001. aasta veebruarinumber (http:// www.devichnik.ru/2001/02/maslo_bliny.html).

reetsesse ajalisse raamistusse: venelased ütlevad Дорого яичко к Великодню, или услуза bовре ля 'Lihavõttemuna on kallis nagu õigeaegne teenegi' (Dal 1955: IV, 675); bulgaarlased lausuvad Като лине Великден червените яица пари не cmpybam 'Pärast lihavõtteid enam punaseid mune ei müüda' ja След Коледa коладеле 'Pärast jõule jõululaule ei laulda' (Slavejkov 1972: 459). Sama mõtet võidakse väljendada ebakohase riietuse kujundi abil. Näiteks Bulgaarias öeldakse С един пантоф Великден прави 'Ta peab lihavõtteid, endal ainult üks king jalas' (Slavejkov 1972: 432); Великден иде, Стоян гасти няиа 'Lihavõtted on tulemas, aga Stojan on püksata' (Slavejkov 1972: 131). Sama saab väljendada ka ebakohase (liiga argipäevase) roa kujundi abil, näiteks bulgaarlased ütlevad Обищал во като лешта на Великден 'Ma armastan teda sama palju nagu läätseleent lihavõttelaual' (Slavejkov 1972: 187), venelased aga Без блина не масляна 'Pliinideta pole võinädalat' (Dal 1955: II, 302).

Veel üks kirikupühade rangele ajastamisele viitavate vanasõnade puhul esinev erijoon on määratluse "mitte kunagi" semantika, nt vene В Вознесенье, когда будет оно В воскресенье 'Taevaminemispühal, kui see langeb pühapäevale' (see püha on alati neljapäeval) (Dal 1955: I, 199) ja bulgaaria На Врабиица в сряда 'Palmipuudepühal, ${ }^{46}$ kui see on kolmapäeval' (see püha on aga alati pühapäeval) (Slavejkov 1972: 300). Väga lähestikku paiknevate pühade seos- 
tamise kaudu viidatakse väga lühikesele ajale, näiteks esineb seda sajatustes: bulgaaria ,Да те пожиъе Господ от Бъдии вечер до Коледа 'Jäägu sul elada jõuluõhtust esimese jõulupühani (tähendus: ma soovin sinu surma)' (Slavejkov 1972: 162) või vene irooniline ütlus Зарекся пить, от Вознесенья до поднесенья 'Ta otsustas loobuda joomisest taevaminemispühast esimese pakkumiseni' (Dal 1955: I, 199).

Iga Euroopa kultuur on välja arendanud viisi rituaalse aasta kajastamiseks vanasõnades, idioomides ja ütlustes. Iga konkreetse rahvapärase ütlustetraditsiooni puhul võivad käsitletavad pühad ja tähtpäevad olla erinevad, kuid nendele ja kalendrirituaalidele viitamisel kehtivad vanasõnades universaalsed võtted, mis on vastavuses selle žanri struktuuriliste ja semiootiliste reeglitega.

Tõlkinud Reet Hiiemäe

Toimetanud Kaspar Jassa ja Maarja Villandi

\section{Kommentaarid}

${ }^{1}$ Käesolevat uurimust toetab Vene Teaduste Akadeemia uurimisprogramm "Structure and linguistic organization of the Slavonic text in synchrony and diachrony", \# 9.1, 2003-2005.

${ }^{2}$ Artiklis kasutatud terminid mõtteterad, vanasõnad, ütlused jne tähistavad erinevaid (suulise) folkloori žanre, mis kujutavad rituaalset aastat eelkõige mingile teatud ajalõigule osutamise kaudu. Lisaks nimetatud žanridele vaatlen ka idioome, võrdlusi ning mõningaid loitse ja sajatusi.

3 Toimetuse kommentaar: Eelija (vene traditsioonis Ilja), Vana Testamendi suurim prohvet, sündis 912. aasta paiku eKr praeguse Jordaania territooriumil Tisbes, suri 850. aastal eKr Jeeriko lähedal. Tegutses Iisraeli jumala Jahve ja ebajumal Baali kultuse vastuseisu ajal. Piiblilegendi järgi ennustas põuda ja läks tuulepöörises tulise vankriga taevasse (ÖKumenisches HeILIGENLEXIKON). Sellest tuleneb nt üks Suure Vankri tähtkuju nimetusi Eelija Vanker. Tema mälestuspäeva tähistatakse nii katoliku kui ka õigeusu kiriku kalendris 20. juulil, vana ehk juuliuse kalendri järgi elavates õigeusu kogudustes 2 . augustil. Vene rahvakalendris, mis tugineb samuti juuliuse kalendrile, tähistatakse iljapäeva 2. augustil. See on oluline suvine pöördepunkt, kust alates hakkavad päevad pöörduma sügisesse ja tehakse algust viljalõikusega (NARODNÕJE PRIMETõ). Eestis on iljapäiv tuntud Setumaal.

${ }^{4}$ Polesje (valgevene keeles IIaлecce (Palessje) ja ukraina keeles IIoлiccя(Polissja)) - soine maa-ala Valgevene ja Ukraina piiril Prõpjatsi (vene k Pripjat) jõe ümbruses. Selle unikaalse arhailise idaslaavi kultuurilise piirkonna kohta vt Tolstaja 2001, 2005.

5 Toimetuse kommentaar: Nn suvine peetripäev, ka peeterpaulipäev, peetripaavlipäev, Rooma ja Antiookia apostlite Peetruse ja Pauluse mälestuspäev.

Peetrus (paavsti, kiriku, kalurite jt kaitsepühak), Joona poeg ja Andrease vend, kandis algul nime Siimon, Peetruse nime (Keefas - kreeka keeles Petra 'kalju') andis talle Jeesus, sest temast pidi saama kalju, millele ehitatakse kristlik kirik. Evan- 
geeliumides on lugu sellest, kuidas Jeesus ennustas, et Peetrus jõuab ta enne kukelaulu kolm korda ära salata. Selle loo sümbol on kirikutornis risti asendav tornikukk. Pärast Jeesuse surma ja ülestõusmist sai Peetrusest Jeruusalemma kristliku koguduse juht. Ta oli esimene imetegusid sooritanud apostel. Peetrust peetakse ka esimeseks paavstiks (VIKIPEEDIA).

Paulus (algselt Saulus), sünd u 3. aastal pKr, oli pärit Tarsosest. Oli algselt kristlaste vastane, kuid u aastal 30 astus ristiusku ja temast sai üks esimesi aktiivseid kristluse kuulutajaid (Saulusest sai Paulus; Pauluse pööramise päeva - paavlipäeva - tähistab ristikirik 25. jaanuaril). Uues Testamendis on Paulusele omistatud 13 kreekakeelset kirja, mh veenab Paulus, et Aabrahami Jumal pole ainult juutide, vaid kõigi inimeste Jumal. Pauluse õpetused on mõjustanud hilisemaid ristiusuvoole, sh reformaator Martin Lutherit (1483-1546) ja 20. sajandi suurimat protestantlikku teoloogi Karl Barthi (1886-1968) (ANTIIGILEKSIKon; VIKIPEEDIA).

Peeterpaulipäeva tähistatakse 258. aastast kogu ristikirikus 29. juunil (sel kuupäeval 258. aastal kaevati mõlema apostili põrmud salaja nende algsest hauast välja - Rooma kristlased kartsid, et vaenlase väed kahjustavad matmispaika - ning Peetrus maeti seejärel Vatikani Püha Peetruse basiilikasse ja Paulus Roomas via Ostienil asuvasse Püha Pauluse basiilikasse), juuliuse kalendrit rakendavad õigeusu kogudused vastavalt 12. juulil. Pärimuse järgi olevat nad hukatud keiser Nero valitsemisajal 66., 66. või 67. aastal (Peetrus löödi pea alaspidi risti, Paulus hukati mõõgaga), nende surmakuupäev on aga aegades ununenud. Läänekirikus tähistatakse paavst Hadrianus I (772-795) ajast apostel Pauluse mälestuspäeva eraldi 30. juunil, samal päeval tähistab evangeelne kirik kõigi Rooma märtrite päeva, idakirik aga tähistab 30. juunil / 13. juulil kõigi 12 apostli mälestuspäeva (ÖKUMENISCHES HEILIGENLEXIKON).

Vene rahvakalendris langeb peeterpaulipäev kirikliku traditsiooni järgi 12. juulile. See on suve kõrgaeg, päikesepüha. Talupoegadel algas kibekiire suviste põllutööde aeg. Päeva tähistati rahvapühana (Петровское гулянъе). See oli ka traditsiooniline laadapäev (NARODNÕJE PRIMETÕ).

Eestis tähistavad peetripäeva kõige suurejoonelisemalt Peipsi ranniku vana kalendri järgi elavad vanausulised Piirissaarel, praktilistel põhjustel on viimasel ajal püha peetud 12. juulile lähimal nädalavahetusel (vt PiIRISSAARE KOGUdus). Päeva tähistatakse ka Setumaal (Kõiva 2004). Uustraditsioonidest mainigem, et Peetruse ja Pauluse kui keskaegse Tartu (ja selle toomkiriku) kaitsepühakute nimepäeva tähistatakse 2003. aastast Tartu linna päevana. Eesti rahvakalendris on väheseid teateid (Läänemaalt ja Hiiumaalt) ka talvisest peetripäevast ehk peetri helinapäevast (22. veebruar), mis on selgelt seotud läänekirikuga - see on Peetruse kateedri (Püha Tooli ehk paavsti kui Peetruse maapealse esindaja) pidupäev -, Peetri ahelatepäeva (8. august) aga peaaegu ei tunta (Kõiva 2004).

${ }^{6}$ Toimetuse kommentaar: Võrdle eesti vanasõnaga Kägu muudab end jaanipäevast saadik raudkulliks (EV 4921:6), mis viitab käo ja raudkulli sarnasusele ning nende äravahetamise võimalusele.

7 Toimetuse kommentaar: Paastumaarjapäev (vene k Блавољещение) on kirikukalendris päev, mil peaingel Gabriel kuulutas Neitsi Maarjale Jeesuslapse sündi üheksa kuu pärast. Kirikliku pärimuse järgi alustas Maarja selle sõnumi järel paastumist. Õigeusu kirikus on see Neitsi Maarja ehk Jumalaema rõõmukuulutamise püha, üks kaksteistpühade (12 olulisemat püha pärast paasapüha) hulka kuuluvaid pühi (EESTI-VENE ÕIGEUSU SELETAV SÕNASTIK). Pärast Venemaa ristiusustamist oli paastumaarjapäev pikka aega kirikuaasta algus, nn märtsikuu uusaasta (nagu seda oli paastumaarjapäev kunagi ka katoliku kirikus), samal ajal kui Venemaa ilmalik aasta al- 
gas 1. septembril. Vene rahvakalendris langeb paastumaarjapäev 7. aprillile ja on nn kolmas kohtumine kevadega (esimene on küünlapäev ja teine sorokasveet ehk tsirgupäiv 9./22. märtsil), sel päeval võidab kevad talve (NARODNÕJE PRIMETõ). Paljud maarjapäevakombed (pliinide küpsetamine, üle lõkke hüppamine, vanade asemeõlgede ja talve sümboliseeriva õlgnuku põletamine jne) sarnanevad võinädala, st muinasslaavi uusaasta tavadele (Kadžaja 2006). Eesti rahvakalendris naistepüha, tuntud nimedega kapsamaarjapäev, punamaarjapäev, kevadine maarjapäev (Kõiva 2004).

8 Toimetuse kommentaar: Läänekirikus 29. septembril (Rooma Püha Miikaeli kiriku pühitsemise päeval) tähistatav peaingel Miikaeli mälestuspäev ehk lihtsalt mihklipäev kannab õigeusu kirikus nime peaingelite Miikaeli, Gaabrieli ja Raafaeli ja kõigi ilmihuta taevaste vägede päev, seda tähistatakse 8./21. novembril (EESTI-VENE ÕIGEUSU SELETAV SÕNASTIK). Selle kuupäeva määras 4. sajandil Laodikeia kirikukogu üheksa inglite klassi järgi tollal märtsiga alanud aasta üheksanda kuu (ladina k November 'üheksas') kaheksandale päevale (sest see oli Matteuse evangeeliumi järgi kohtupäev pärast seitset loomispäeva, mil Inimese Poeg pidi tulema koos kõigi oma inglitega Jumala palge ette). Vene rahvakalendris tähistatakse mihklipäeva 21. novembril, sellest ajast algab veekogude kaanetumine, tuntud on ka väljend лихайловские грязи 'mihklipäeva pori' (NARODNÕJE PRIмETõ). Eestis tähistatakse novembrikuist mihalapäiva Setumaal.

9 Toimetuse kommentaar: Jevdokia (Evdokia, Eudokia, Eudoxia), katoliku ja õigeusu kiriku pühak, sündinud Liibanonis Heliopolis. Veetis pärast seda, kui oli lasknud piiskop Theodotosel end ristida, 56 aastat kloostris, kus saatis korda arvukalt imetegusid, sh äratas ellu surnuid. Vangistati ja hukati 160.-170. aasta paiku kristlaste tagakiusamise käigus. Tema mälestuspäeva peavad nii lääne- kui ka idakirik 1. märtsil, vana kalendri järgi elavad õigeusu kogudused 14. märtsil (vt ka GLAUBENSZEUGEN). Vene rahvakalendris nimetatakse jevdokiapäeva Евдокия ІІлющиха 'Lapikukslitsutud Jevdokia' - see nimi tuleneb märtsi keskpaigaks maadligi vajunud lumest. Jevdokiapäeva ilm on olulisimaid suveilma ennustajaid (NARODNÕJE PRIMETÕ). Eestis on jevdokiapäev isegi Setumaal väheoluline (Kõiva 2004).

10 Toimetuse kommentaar: Vene õigeusu kirikukalendris on dimitripäev suurmärter Demetriose (Thessaloníki Püha Demetrius, vene traditsioonis D(i)mitri Solunski) surma (u 305. või 306. a) mälestuspäev (WIKIPEDIA). Demetrius oli Rooma sõjaväelane, Püha Rüütel. On Konstantinopoli, Thessaloníki ja Veneetsia patroon. Dimitripäeva tähistavad nii katoliku kui ka õigeusu kirik 26. oktoobril (vt GLAUBENSZEUGEN), vana kalendri järgi elavad õigeusu kogudused aga 8. novembril. Vene rahvakalendris on oluline tähtpäev ka surnute mälestuspäevana tuntud dimitri laupäev, s.o dimitripäevale eelnev laupäev, mida seostatakse hoopis teise Püha Dimitri, nimelt Moskva suurvürsti Dmitri Donskoi (1359-1389) võiduga tatarlaste üle Kulikovo lahingus 1380. aastal (vt NARODNÕJE PRIMETÕ; RITUAL.RU), kelle mälestuspäev on hoopis 19. mail / 1. juunil (PravoslavNõI KALENDAR 2006). Setumaalt on mõningaid teateid sügisese vanemate laupäeva tähistamisest, kuid see ei kattu ajaliselt dimitri laupäevaga (SETUKAISTEN YSTÄVÄT-YHDISTYS). Samas on Setumaa dimitripäev ehk midruskipäev (algselt 26. oktoober) võtnud üle hoopis dimitri laupäeva hingede- ja kalmistupäevafunktsiooni ning nihkunud omakorda evangeelsele usupuhastuspühale, 31. oktoobrile (Kõiva 2004).

11 Toimetuse kommentaar: 24. juuli / 6. august on Venemaa ristiusustaja (988) Kiievi suurvürsti Vladimir I (948 - 15.07.1015) poegade Borisi ja Glebi surma mälestuspäev. Vürstid Boris Rostovski ja Gleb Muromski tapeti pärast isa surma 1015. aasta 24. juulil. 1072. aastal kuulutati nad õigeusu pühakuteks (HRONOS). Esimesi Kiievi 
Venemaa oma pühakuid, kelle mälestuspäevi tähistatakse mõistetavalt eriti praeguse Ukraina aladel. Põllunduskalendris seostub suvine borisi- ja glebipäev viljakoristuse algusega (NARODNÕJE PRIMETÕ).

12 Toimetuse kommentaar: Püha Florus (Floros) ja Püha Laurus (Lavros) olid kristlikud märtrid, kes elasid Bütsantsis ja Illüürias 2. sajandil pKr. Nad olid kaksikvennad ning töötasid müüriladujate-kiviraiduritena. Ühel päeval olid nende hobused kadunud. Nad pöördusid peaingel Miikaeli poole, et oma ratsud tagasi saada. Peaingel aitaski neid ning vennad otsustasid pühendada oma elu hobustele ning nende aitamisele ja ravimisele. Seetõttu said nendest Venemaal hobuste kaitsepühakud. Vene õigeusu kirik peab neid au sees tänini (vt Shilov). Kristianiseerisid paganliku templi ja müüriti lõpuks sellesse (Saints \& Angels). Frolipäeva tähistatakse 18. augustil, vana kalendri järgi elavates õigeusu kogudustes 31. augustil. Vene rahvakalendris, kus püha langeb samuti augustikuu viimasele päevale, on see hobustepüha, kuid tähendab ka taliviljakülvi lõppu ja naiste tubaste tööde algust (NARODNÕJE PRIMETÕ).

${ }^{13}$ Kalender - sellisel kujul, nagu sellest räägitakse massimeedias ja argivestluses - on muutunud. Inimesed ei kasuta aja liigendamisel kalendrikuid ega ametlikke tähtpäevi, vaid kirikupühasid ja rahvakalendri tähtpäevi. Võinädal on üks populaarsemaid ajalisi määratlusi, mis on eriti armastatud ka reklaamides. Vt ka veebilehti, mis sisaldavad kalendrilisi vanasõnu, ennustusi ja ilmaga seotud uskumusi: http:// www.token.ru; http://primeti.chat.ru; http://www.days.ru; http://www.devichnik.ru jt.

${ }^{14}$ Paastumaarjapäev langeb gregooriuse kalendris 7. aprillile uues, gregooriuse kalendris, sest Vene Õigeusu Kirik elab vana, juuliuse kalendri järgi.

15 Toimetuse kommentaar: Aamos - Vana Testamendi prohveteid, Tekoa karjane, tegutses aastatel 760-750 eKr. On pannud oma raamatus kirja selle, mis ta nägi Iisraeli kohta Juuda kuninga Ussija päevil ja Iisraeli kuninga Jerobeami, Joase poja päevil kaks aastat enne maavärisemist. Aamose mälestuspäeva tähistavad nii lääne- kui ka idakirik 15. juunil (ÖKUMENISCHEs HEILIGENLEXIKON), juuliuse kalendri järgi elavad õigeusu kogudused 28. juunil. Vene rahvakalendris on prohvet Aamose ja märter Viituse ühine mälestuspäev üsna väheoluline, kuid tuntud nt kui odraorase rohetama hakkamise aeg.

16 Toimetuse kommentaar: Püha Paraskeeva Pjatnitsa sündis Ikonias (tänapäeval Türgi linn Konya) jõuka kristlase tütrena ja suri samas 303. aastal. Tema lisanimi tähendab reedet, nädalavahetuse eelpäeva, aga ka Kristuse kannatamispäeva. Idakirikus käibivate legendide järgi ristiti ta reedel, läänekirik väidab, et ta olla sündinud reedel. Paraskeeva sai kuulsaks jutlustajana. Kohtus kinnitas ta end olevat kristlase, mispeale ta hukati. Eboia Johannes (hilisem õigeusu pühak, u 1690 - 27.05.1730) on pannud kirja tema kannatusloo (ÖKumenisches HeILIGENLEXIKON). Suurmärter Paraskeeva mälestuspäeva ehk Paraskeeva reedet tähistatakse 28. oktoobril (vana kalendri järgi elavates vene õigeusu kogudustes 10. novembril). Paraskeeva mälestuspäeva paigutamine mõningates tekstides 14 . oktoobrile võib olla tingitud selle püha ühtesulamisest pokroviga (vt ka kommentaar 21). Paraskeeva oli naiste eestkostja ja vene rahvakalendris tähendas Paraskeeva reede linapäeva ehk lõugutamispäeva - siis alustati linatöödega (NARODNõJE PRIMETõ). Suurkannataja Paraskeeva sügisest mälestuspäeva tähistatakse Setumaal rämmänipäiva nime all, kuid sealgi on tuntum suvine paraskeevapäev (26. juuli / 8. august) ehk päätnits, mida tähistatakse suurelt Saatses, kus asub tema nimikirik.

17 Toimetuse kommentaar: Märtrisurma surnud apostel Andrease surma mälestuspäev. Siimon Peetruse vend Andreas oli Jeesus Kristuse kaasaegne ja üks tema 
esimesi jüngreid. Jeesuse jüngrina tegi ta misjonitööd Väike-Aasias ja Sküütias. Löödi Kreekas Patrases 30. novembril 60. aastal diagonaalristi - sellist risti nimetataksegi Andrease ristiks (ÖKumenisches Heiligenlexikon). Paljude elukutsete, suhete, haiguste ja paikade, sh ka Venemaa kaitsepühak. Pärimuse järgi peatus ta oma kuulutusreisil Kiievi küngastel ja õnnistas tulevast linna. Andresepäeva tähistatakse 30. novembril / 13. detsembril. Vene rahvakalendris on день Андрея ІІер6озъанново (Andreas Esmakutsutu päev) veekuulamise päev (vaikne vesi tähendab ilusat talve, kohisev vesi pakast, tormi ja tuisku (NARODNÕJE PRIMETõ). Läänekiriku mõjualadel, sh Eestis märgib andresepäev sageli advendiaja ehk jõuluootuse algust.

18 Toimetuse kommentaar: Küünlapäev on idakirikus seotud Kristuse esimese templisse viimisega (issanda templisseviimise päev), läänekirikus aga tuntud kui Maarja puhastamise päev 40 päeva pärast Kristuse sündi (küünlamaarjapäev). Püha tähistamine algas Bütsantsis 4. sajandil ja Roomas 7. sajandil. 11. sajandist (Kõiva 2004). Küünlapäeva tähistatakse 2. veebruaril, juuliuse kalendri järgi elavates õigeusu kogudustes 15 . veebruaril. Vene rahvakalendris langeb küünlapäev (Сретенъe) samuti 15. veebruarile ja on see päev, kus talv kohtub esimest korda kevade ja suvega, seega talve murdepunkt (NARODNÕJE PRIMETõ).

19 Toimetuse kommentaar: 14./27. septembril tähistavad nii õigeusu kui ka katoliku kirik Kristuse risti leidmist Jeesuse hauakoopast keisrinna Helena, Constantinus I ema poolt 326. aastal, mil ta sooritas oma poja patutegude kahetsuseks esimese palverännaku pühasse linna Jeruusalemma. Sealtsamast leidis Helena ka tahvli, millele oli kirjutatud I.N.R.I. (Jeesus Naatsaretist Juudamaa kuningas) (WF-F 2006). Setu traditsioonis tähistatakse ristiülendamise püha vissenja nime all.

20 Toimetuse kommentaar: Kui Maarja oli saanud kolmeaastaseks, viisid isa Joakim ja ema Anna ta Jeruusalemma templisse. Maarja pandi seisma templitrepi kõige madalamale astmele. Üleval ootas teda ülempreester Sakarias. Kõikide imestuseks ja kehtivate traditsioonide vastaselt astus Maarja ise ülempreestri juurde viivad 15 trepiastet. Jumalast juhatatuna viis ülempreester Maarja templi pühimasse pai$\mathrm{ka}$, kuhu tal endal oli lubatud siseneda vaid korra aastas. Templis kasvas Maarja koos teiste oma elu Jumalale pühendanud naistega. Nad palvetasid, lugesid pühi kirjutisi ja täitsid neile usaldatud tööülesandeid. Maarja andis Jumalale tõotuse jääda igavesti neitsiks. Püha Vaimu arm kaitses tema südant kõige ebapuhta eest (ÕIgEUSU KIRIKU PÜHADEKALENDER). Tähistatakse 21. novembril / 4. detsembril. Vene rahvakalendris on vvedenje (Вלеденъе) talve väravaks (NARODNõJE PRIMETõ). Eestis vähetuntud katoliiklik ja õigeusklike tähtpäev leemetimaarjapäev ehk templimaarjapäev.

21 Toimetuse kommentaar: Pokrov ehk Jumalaema eestkoste ja kaitse püha. Kuulub suurte ja oluliste õigeusu pühade hulka, tähistatakse 1. oktoobril, vana kalendri järgi elavates kogudustes 14. oktoobril. Jumalaema kaitsmise püha tähistatakse Kristuse pärast meeletule Andreasele ja tema õpilasele Epifanesele 5. sajandil (teistel andmetel aastal 903) osaks saanud ilmutuse mälestuseks. Nimelt nägid nad öösel Konstantinopoli Blaherna kirikus, kus usklikud Jumalaema poole palvetasid, et see linna vaenlase eest kaitseks, kuidas Neitsi Maarja oli äkki inglitest ümbritsetuna taevas, palvetas usklike eest ja laotas oma keebi nende üle. Alates 12. sajandist hakati Venemaal ehitama Pokrovi kloostreid ja kirikuid. Läänekirikus on alates 13. sajandit Neitsi Maarjat sageli kujutatud "kaitsemantliga madonnana", kes võtab usklikud oma hõlma alla (GLAUBENSZEUGEN). Vene rahvakalendris tähendab pokrov sügistööde lõppu ning talve ja sügistalvise pulmaperioodi algust (NARODNÕJE PRIMETÕ). Eestis tähistatakse Setumaal Jumalasünnitaja kaitsmise püha nime all, 
ajalise läheduse tõttu on see kokku sulanud läänekiriku mihklipäevaga. Ka on õigeusklikud rajanud Eestisse Jumalaema Kaitsmise kirikuid: Karula Jumalasünnitaja Kaitsmise kirik, Tornimäe Neitsi Maria Kaitsmise kirik, Kiviõli Jumalaema Kaitsmise kirik, Nina Jumalaema Kaitsmise kirik (VIKIPEEDIA). Pokrovi on eesti keeles nimetatud ka suurmaarjapäevaks.

${ }^{22}$ Polesjes tähendab see päev rahvaetümoloogia järgi väljamõeldud Püha Pokrova mälestuspäeva.

${ }^{23}$ Toimetuse kommentaar: Püha Luukas, apostel ja üks neljast evangelistist, sündis tänapäeva Türgi aladel, suri 80. aastal pKr Türgis või Kreekas, Luuka evangeeliumi, ühe olulisima Jeesus Kristuse elu käsitleva allika oletatav autor. Püha Luukas on arstide, kirurgide ja maalikunstnike, skulptorite, raamatuköitjate, lihunike kaitsepühak. Olulisim tema mitmetest mälestuspäevadest on 18./31. oktoober. Kuid õigeusu kalendris on ka teiste $L u k$-silbiga algavate pühakute mälestuspäevi, nt rahvakalendris Tuuletegijana tuntud Lukillianuse päev 3./16. juunil (NARODNÕJE PRIMETÕ).

${ }^{24}$ Toimetuse kommentaar: Helena Flavia (surnud u 326), trahteriteenija, kelle keiser Constantius võttis liignaiseks, kuid hiljem hülgas. Poeg Constantinus I tõi ema õukonda tagasi. Helena võttis vastu ristiusu ja sooritas palverännaku Jeruusalemma. Pärast surma hakati teda pidama naelaseppade patrooniks, õigeusu kirik austab teda pühakuna, tähistades tema päeva 21. mail / 3. juunil (ANTIIGILEKSIKoN). Vt ka ristiülendamise püha (kommentaar 19).

25 Toimetuse kommentaar: Püha Makrida (noorem), idakiriku andmetel sündinud 327. aastal, läänekiriku andmetel 330. aastal, Püha Basilius Suure ja Nyssa Gregoriuse (kes ka tema elukäigu kirja pani) vanem õde. Pärast kihlatu surma tõmbus elust tagasi, alates 352. aastast juhatas nunnakloostrit. Tal olid head käsitööoskused ja haridus. Püha Makrida mälestuspäeva tähistatakse 19. juunil, vana kalendri järgi elavates õigeusu kogudustes 1 . augustil (WIKIPEDIA). Vene rahvakalendris tähendab see päev sügisesse vaatamise algust, selle päeva järgi ennustatakse kogu sügise ilma (NARODNÕJE PRIMETÕ).

26 Toimetuse kommentaar: Püha suurmärter Mokius (Mokios) elas keiser Diocletianuse ajal (284-305) ja oli Amphipolise preester. Dionysose pidustuste ajal kutsus paganaid ristiusku pöörduma, mispeale ta kinni võeti ja Konstantinopoli saadeti. Seal raiuti tal aastal 295 (või 304) pea maha. Keiser Constantinus laskis tema auks ehitada kiriku, kuhu maeti ka Mokiuse säilmed. Läänekirik tähistab Mokiuse mälestuspäeva 13. mail, idakirik 11./24. mail (ÖKumENisches HeILIGENLEXIKoN). Vene rahvakalendris peetakse mokiusepäeva ilma kogu suvise ilma ennustajaks - kui sel päeval sajab, tuleb suvi vihmane (NARODNÕJE PRIMETõ).

${ }^{27}$ Toimetuse kommentaar: Piibli apogrüüfide hulka kuuluva 2. Makabite raamatu 7. peatükk räägib seitsme venna ja nende ema Salomonia märtrisurmast kuningas Antiochose IV ajal (175-164 eKr). Selle juudi perekonna märtrisurm viis Juudas Makabeuse ülestõusu puhkemiseni. Makebeide ülestõusuna ajalukku läinud ürituse käigus tõrjusid iisraeliidid Juudas Makabeuse juhtimisel kreeklased Jeruusalemmast 164. aastal eKr välja. Märtrite Makabeide mälestuspäeva tähistab õigeusu kirik alates 4. sajandist 1./14. augustil, läänekirik tähistab seda 8. sajandist (GLAUBENsZEUGEN). Õigeusklikel algab sel päeval rukkimaarjapäevani (Jumalaema uinumise pühani) kestev jumalaema paast. Õigeusu kirikus on see ristipuu väljatoomise päev. Vene rahvakalendri järgi on see esimene suve ärasaatmise püha, õigeusu kirikus üks suvistest Lunastaja (Спаситель) äraseletamise pühadest ehk paasadest, nimelt meepaasa ehk meepüha (Медовый Cnac) - meevurritamise aeg -, millele järgnevad 
ounapüha ehk õunapaasa issandamuutmise pühal (vt kommentaar 33) ja lõikuspüha ehk leivapaasa (Спожинки) rukkimaarjapäeva (Jumalaema uinumise püha) järelpäeval (NARODNÕJE PRIMETÕ). Eestis on makaveipäev kui õigeusupüha tuntud üksnes setudel (Kõiva 2004).

28 Toimetuse kommentaar: Uue Testamendi Apostlite tegude 10. peatükk räägib Rooma tsentuuriost Korneeliusest, keda Peetrus oli ristinud ja kellest seetõttu sai esimene pagankristlane. Tema ristimine ilma juudiks saamata viis ristikiriku lahutamiseni juutlusest. Legendi kohaselt järgnes Korneelius Peetrusele misjonireisidele, hiljem sai temast kodulinna Kaisarea piiskop ja ta elas kõrge vanuseni. Katoliku kirik tähistab Korneeliuse mälestuspäeva 2. veebruaril ja õigeusu kirik 13./26. septembril (GLaUbenszeugen). Vene rahvakalendris tähendab see aega, mil maa hakkab juba külmuma (NARODNÕJE PRIMETÕ).

29 Toimetuse kommentaar: Korinfskil (1994) on Püha Korneeliuse päevana märgitud (ekslikult?) 12. september.

30 Toimetuse kommentaar: Märter Gordius (sündinud ilmselt 3. sajandi lõpul Kapadookias Kaisareas, hukatud 4. sajandil sealsamas) oli pärimuse järgi Rooma tsentuurio, kes hukkamistest vapustatuna loobus väeteenistusest ja elas Siinai mäel erakuna. Pöördunud 306. (või 320.) aastal tagasi kodulinna, kritiseeris ta paganlikku kultuuri ning tutvustas end kristlasena. Et ta jäi selles endale kindlaks, siis ta hukati. Tema mälestuspäeva tähistavad nii katoliiklik, evangeelne kui ka õigeusu kirik 3. jaanuaril, vana kalendri järgi elavad õigeusu kogudused 16. jaanuaril (ÖKUmenisches Heiligenlexikon; GLaubenszeugen). Vene rahvakalendris väheoluline tähtpäev.

31 Toimetuse kommentaar: Nahum, üks kaheteistkümnest Vana Testamendi prohvetist, elas 7. sajandil eKr Galileas ja olevat pärimuse järgi surnud 45-aastasena. Kirjutas ennustuse Niineve hävingu kohta. Tema mälestuspäeva tähistab vaid idakirik (1./14. detsembril).

32 Toimetuse kommentaar: Taevaminemispüha ehk suur ristipäev, lihavõttetsükli liikuv püha, neljakümnes päev pärast 1. ülestõusmispüha, seega kuuenda lihavõttejärgse nädala neljapäev. Idakirikus on see püha tuntud kui analepsis, ülestõstmine, aga ka episozomene, päästmine, sest astudes jumalikku kirikusse viis Kristus lõpule inimkonna lunastamise patust. Läänekirikus on selle päeva nimetus ladinakeelne Ascensio, mis annab mõista, et taevaminek polnud Kristuse poolt vaid passiivne minemine, vaid ta läks Isa juurde oma väe varal. Pärimuse kohaselt lahkus Kristus maa pealt Jeruusalemma lähedal Õlimäel. Taevaminemispüha tähistamist on dokumenteeritud 4.-5. sajandist. Läänekirikus asetus taevaminemispüha suurimate pühade hulka ja ka idakirikus kulub see kaheteistkümne suurema püha ehk kaksteistpühade hulka (CATHOLIC ENCYCLOPEDIA).

${ }^{33}$ Toimetuse kommentaar: Issandamuutmise püha ehk Jeesuse kirgastamise päev ilmus Ida-Süüria liturgiasse juba 5. sajandil. Läänekirikus tekkisid esimesed analoogid 10. sajandil. 1451. aastal kinnitas paavst Calixtus III selle Belgradi juures türklaste üle saavutatud võidu tähistamiseks tervele kirikule määratud kalendrisse. Issandamuutmise püha tähistab kogu ristikirik 6. augustil (VIKIPEEDIA; GLAUBENSZEUGEN), vana kalendri järgi elavad õigeusu kogudused aga 19. augustil. Rahvakalendris kannab nimetust õunapaasa (Яблочный Спас) (vt ka kommentaar 27), mis tähendab ounakoristuspäeva. Setumaal tuntud paasapäevana.

34 Toimetuse kommentaar: Õigeusu kirikukalendris ja vene rahvakalendris on mitu alekseipäeva, neist tuntuim vaga Aleksius Jumalamehe (elas väidetavalt 5. sajan- 
dil) mälestuspäev 17./30. märtsil (Kõiva 2004). Varasemate legendide järgi oli ta sündinud Édessas (Türgis), teiste järgi oli Rooma senaatori poeg. Kohe pärast laulatust tagastas ta pruudile abielusõrmuse ja lahkus salaja kodust, et pühenduda usule. 17 askeetliku ränduriaasta järel jõudis ta kerjusena isamaja trepi ette. Aleksiust ei tundnud ära isa ega naine, kerjaja isik sai teatavaks alles pärast tema surma tema juurest leitud kirja järgi, milles ta enda isiku avalikustas ning pruudilt ja vanematelt andestust palus. Pärast surma kuulutati ta pühameheks, tema isakodust ehitati kirik ja Aleksiusest sai selle patroon. Tema põrm puhkab Roomas Bonifatsiuse kirikus (praegu Bonifatsiuse ja Aleksiuse kirik). Õigeusu kirikus on Aleksius Jumalamees senini väga austatud pühak, kuid ka katoliku kirikus kuulus ta barokiajani populaarsemate pühameeste hulka (GLAUBENSZEUGEN). Katoliku kirikus hakati 1697. aastal (Aleksiuse oletatavast 417. surma-aastast) Aleksiuse mälestuspäevana tähistama 17. juulit. Vene rahvakalendris langeb see nn Soe-Aleksei ehk kevadine alekseipäev greogooriuse kalendris 30. märtsile - sellest päevast hakati valmistuma kevadeks (NARODNÕJE PRIMETõ). Eestis on 17. märtsil tähistatav alekseipäev mõnevõrra tuntud nt setudel.

Teine vene rahvakalendrisse kandunud alekseipäev on metropoliit Aleksei mälestuspäev 12./25. veebruaril. See õigeusu pühamees sündis 1293 või 1304 Moskva bojaariperekonnas ja siirdus 15-aastasena kloostrisse, kus võttis endale nimeks Aleksei. 1338. aastast Moskva metropoliidi abiline juriidilistes küsimustes, 1350. aastast Vladimiri piiskop ja 1354. aastast metropoliit. Tema metropoliidiks olemise ajal saavutati üksteisemõistmine Leedu ja Volõõnia (Ukraina) metropoliitidega, selleks reisis Aleksid 1356. aastal ka oikumeenilise patriarhi Kallistose juurde Konstantinopolisse. Kallistos nimetas ta Kiievi peapiiskopiks ja kogu Venemaa metropoliidiks. Tööka ja innustunud metropoliidina nimetas ta ametisse hulga piiskoppe ja rajas mitmeid kloostreid, sh Andronnikovi kloostri. Kõige muu kõrval suutis ta tänu pimeda vürstinna Tadjula terveksravimisele hoida korras ajalooliselt keerukaid suhteid Kuldhordi khaaniga. Tajudes Moskva kasvavat tähtsust, viis 1362. aastal metropoliidi residentsi Vladimirist Moskvasse. Suri 12. veebruaril 1378 ja on maetud Tšudovi kloostrisse. Pool sajandit pärast tema surma leiti tema haud imelistel asjaoludel üles ja sealtpeale algas metropoliit Aleksei austamine, ta on üks Moskva kaitsepühakuid (GLAUBENZEUGEN). Vene rahvakalendris tähistatakse talvist alekseipäeva 25. veebruaril. Vanasti oli see aeg, mil seemned viidi korraks külma kätte - alekseipäeva pakane karastas nisuseemneid (see oli sisuliselt jaroviseerimine), nii et need andsid paremat saaki. Ka tuli sel päeval ette näidata kedrused, mis pidid olema valmis juba Püha Blasiuse mälestuspäevaks, vene rahvakalendris lehmapühana tähistavaks ulasepäevaks, mida tähistatakse päev varem - 11./24. veebruaril. Päeva on nimetatud ka kalaalekseipäevaks (NARODNõI KALENDAR). See nimetus tuleneb arvamusest, et kui alekseipäeval on kusagil veeniresid, tuleb hakata kala püüdma. Sedasama käsku, et veeniresid nähes tuleb minna kalale, on toonitatud ka märtsikuise alekseipäeva puhul.

35 Toimetuse kommentaar: Püha Nikolause ehk Nikolai Imetegijaga seotud pühad. Myra piiskopi Nikolause (kes olevat sündinud Patarase linnas Väike-Aasias Rooma riigi Lüükia provintsis u 282 ja surnud 342. ja 351. aasta vahel Myras) fiktiivse eluloo pani 9. sajandil kirja Metodius, väites, et Nikolaus oli üks 318 kirikuisast, kes võtsid 325. aastal osa Nikaias peetud I oikumeenilisest kirikukogust (Kõiva 2004). Pühast Nikolausest räägitakse rohkesti legende, neist tuntuim on lugu vaese mehe kolmest tütrest, kelle ta päästis vaesuse tõttu prostituudiks saatmisest, visates kolmel järjestikusel ööl nende aknast sisse kullakoti (või kuldmündi). Püha Nikolaus on laste, pandimajapidajate, vallaliste tüdrukute, kaupmeeste, apteekrite, parfüü- 
mitootjate ja -müüjate, meremeeste ja kalurite kaitsepühak. Ta on ka üks Venemaa kaitsepühakutest. Läänekiriku mõjupiirikonnas on tal oluline roll jõuluvana (Santa Claus) prototüübina. Vene õigeusu kirikus on Püha Nikolaus Kristuse ning Neitsi Maarja järel armastatuim pühak ja patroon. Venemaal kujunes Nikolaus (Nikolai) lihtrahva seas kõikvõimsaks aitajaks ja pooljumalaks. On väidetud, et pole linna, kus ei leidu Pühale Nikolause kirikut või kloostrit (VIKIPEEDIA). Püha Nikolaus suri 6. detsembril ja talvine nigulapäev kinnistus sellele päevale 13. sajandil. Kui moslemid 1087. aastal Myra vallutasid, viidi Nikolause säilmed Lõuna-Itaaliasse Bari linna. Seda sündmust meenutab kevadine nigulapäev (Kõiva 2004). Kevadist nigulapäeva (migulapäiv), mis on 9. mail, kuid langeb vana kalendri järgi elavates õigeusu kogudustes 22. maile, tähistavad Eestis valdavalt setud (Kõiva 2004). Vene rahvakalendris nimetatakse seda päeva kevadiseks nigulapäevaks ehk Soojaks Nikolaiks. Sellest päevast hakkavat rohi kasvama. Talvist nigulapäeva - Püha Nikolause surma mälestuspäeva - tähistatakse 6./19. detsembril. Vene rahvakalendris, kus see päev langeb uues ehk gregooriuse kalendris 19. detsembrile, toob Nigul pakast ja lund (NARODNÕI KALENDAR). Eestis tuntud eelkõige setude seas talvise migulapäiva nime all kui üks külmenemise tähiseid.

36 Toimetuse kommentaar: Püha Jüri (Georg, vene traditsioonis Juri, Jegori), sündinud 3. sajandil Kapadookias, surnud 305. aastal Lüddas (Lodis) Palestiinas (Iisraelis), märter ja Inglismaa patroon, kelle kultus oli levinud juba kristluse algusajal. Ohtralt on legende tema imetegudest, kuid nende ajalooline algupära on kaheldav. Püha Jüri on legendi järgi kolm korda surmatud, lõigatud väikesteks tükkideks, maetud sügavale maa alla, kuid tõusnud jumala väe läbi tervena üles. Lisaks kõnelevad legendid vägede peatamistest, lehtivatest sauadest, surnute elustamistest ja paljudest muudest imetegudest. Tänapäeval on tema imetegudest tuntuim lohemao tapmine ja printsessi vabastamine. On säilinud teisigi pärimusi tema rüütellikkusest ja vaprusest, seetõttu on paljudes riikides asutatud temanimelisi ordeneid, ta on sõjameeste kaitsepühak, oma nime tõttu (Georgius tähendab maaharijat) põllunduse patroon, hobuste ja teiste kariloomade kaitsja. Teda austati ka hospidalide pühakuna (Kõiva 2004). Üldtuntud mälestuspäev on 23. aprill (vana kalendri järgi elavates õigeusu kogudustes 6. mai, mida Eestis, eelkõige Setumaal tuntakse nn vene jüripäevana. Õigeusu kirikus tähistatakse ka Kiievi Gregoriuse kiriku pühitsemise päeva 26. novembrit / 6. detsembrit - see on nn talvine jüripäev (ÖKUMENISCHES HEILIGENLEXIKON). Vene rahvakalendris on kevadine jüripäev karjalaskepäev,jüripäevanädalal pidavat kohale jõudma pääsukesed. Talvine jüripäev ehk Külm Jüri oli kunagi Venemaal talupoegade kolimise päevaks ühe mõisniku juurest teise juurde, see aga keelati 1649. aasta kirikukogu seadusega (siit ka vanasõna Вот тебе, бабушка, и Юръеъ день!' 'Vaat sulle, eit, jüripäeva!'; vt NARODNõJE PRIMETõ). Eesti rahvakalendris on oluline vaid kevadine jüripäev, seda nii karjalaskepäeva kui ka talupoegade kolimise päevana, kuid see on saanud 1434. aasta jüriööl puhkenud Jüriöö ülestõusu mälestuseks ka kangelaspäeva varjundi.

37 Toimetuse kommentaar: Luuka evangeeliumi kohaselt sündis Ristija Johannes kuus kuud enne Kristust ja oli tema emapoolne sugulane. Kütkestava jutlustajana pööras ta paljusid oma usku, oli kuulus prohvet ja ristija, mille tõttu pälvis juba eluajal hüüdnime Ristija Johannes. Johannesega on seotud mitmed maailmakirjanduses korduvalt läbi kirjutatud lood, mille hulka kuulub lugu tema äkilisest surmast. Nimelt nõudis noor tantsija Salome valitsejalt, kes oli lubanud täita iga ta soovi, et talle toodaks kandikul Ristija Johannese pea. Salome sai soovitu, ehkki valitseja kahetses oma rumalat lubadust ja rahvas oli löödud prohveti totrast surmast. Ristija Johannese surmapäevaks peetakse 29. augustit, eriliselt ja tuletegemisega tähistatakse aga 
tema sünnipäeva eelõhtut ehk jaanilaupäeva, 23. juunit (Kõiva 2004). Lisaks Ristija Johannese sünni- (24. juuni / 7. juuli) ja surma- ehk pea maharaiumise päevale (29. august / 11. september) on õigeusu kirikukalendris veel Ristija Johannese üldine mälestuspäev (7./20. jaanuar), Ristija Johannese pea 1. ja 2. leidmise (24. veebruar / 9. märts) ja 3. leidmise (päev 25. mai / 7. juuni) ning Ristija Johannese eostamise päev (23. september / 6. oktoober). Vene rahvakalendris on leidnud märkimist Ristija Johannese pea leidmise päevad (ИВаноһ денъ) 9. märtsil lindude saabumise päeva ja 7. juunil meetaimede õitsema hakkamise päevana, mõistagi ka gregooriuse kalendris 7. juulile langev juuliuse kalendri järgne jaanipäev (Иоани Креститель, Иван Kynaлa), mille eelõhtu ja -ööga kaasneb palju paganlikke päikese ja veega seotud kombeid, ning 11. septembril Ristija Johannese surmapäev paastupäevana, mil mehed kohtuvad sügisega, aga vanadele naistele algab nende suvi (NARODNõJE PRIMETÕ). Lisaks Ristija Johannesega seotud päevadele on õigeusu kiriku- (ja vene rahva)kalendris veel mitme püha Johannesega, mh apostel Johannese ja Eboia Johannesga seotud päevad. Eestis tuntakse eelkõige Ristija Johannese sünnipäeva ehk jaanipäeva (Kõiva 2004), Setumaal ka tema surmapäeva ehk ivanoskoroonat (Kõiva 2004).

38 Toimetuse kommentaar: Püha Barbara (slaavi traditsioonis Varvara) olevat sündinud 3. sajandi lõpul Nikomedias (tänapäeva Izmit) või Liibanonis Heliopolises (tänapäeva Ba'labakk), suri 306. aastal Nikomedias. Ta võis olla Galerius Valerius Maximinuse valitsemise aegne märter Daja, kuid on siiski pigem väljamõeldud tegelane, ent sellele vaatamata tuntumaid kristlikke pühakuid. Legendid räägivad eelkõige Barbara ilust ja teravast mõistusest. Tema saatuse kohta on erinevaid legende, neist ühe järgi olla tema kurja isa tabanud piksenool, kui usukindlat tütart hukati. Igatahes on ta kaevurite, vangide, kindlustuste, müürseppade, ehitusmeistrite, kiviraidurite, kellavalajate, hauakaevajate, tuletõrjujate, relvaseppade ja veel paljude ametimeeste kaitsepühak, aitab välgu, tulekahju, palaviku, katku ja äkksurma korral (ÖKUMENisches HEILIGENLEXIKON). Barbara mälestuspäeva tähistatakse 4. detsembril, vana kalendri järgi elavates õigeusu kogudustes 17 . detsembril. Vene rahvakalendri järgi valitsab barbarapäeval (Варварин день) eriti suur külm, millega pakane kaanetab veekogud lõplikult (NARODNÕJE PRIMETõ).

39 Toimetuse kommentaar: Sabbas (slaavi traditsioonis Savva) Pühitsetu sündis 439. aastal Väike-Aasias Kaisarea lähedal. Hakkas erakuks ja elas koopas, kuid hiljem lahkus sealt ning rajas 483. aastal Jeruusalemma lähedale Kidroni jõe kaldale kloostri, kuhu tema surma ajaks (aastal 532) oli kogunenud umbes 500 munka. Koostas kloostri esimese jumalateenistuste korra (tüpikoni), nn Jeruusalemma teenistuskorra, mida hiljem rakendasid kõik Palestiina kloostrid. Tema säilmed on rännanud korduvalt - algul moslemite vallutuste eest Konstantinoopoli ja sealt Veneetsiasse, 24. oktoobril 1965 aga tagasi Jeruusalemma. Sabba rajatud kloostrit, mida tema auks nimetatakse Mar Saba, on korduvalt laiendatud. Praegugi elatakse selles vanimas õigeusu kloostris Sabba koostatud jumalateenistuste korra alusel nagu 1500 aasta eest ning mungad palvetavad iga päev tema hauakambris (ÖKUMENISCHES Heiligenlexikon, GLaubenszeugen). Sabba mälestuspäeva tähistatakse nii lääne- kui ka idakirikus 5. detsembril, vana kalendri järgi elavates õigeusu kogudustes 18. detsembril.

40 Toimetuse kommentaar: Ganka = Õiglane Anna, Neitsi Maarja ema, kelle eostumispäeva tähistatakse 9. detsembril (Neitsi Maarja sünnipäev on teatavasti 9. septembril, ussimaarjapäeval), vana kalendri järgi elavates õigeusu kogudustes 22 . detsembril. Vene rahvakalendris kannab see nime talvine annepäev/annapäev (Анна Зилняя) vastukaaluks Jumalaema ema uinumist tähistavale suvisele annepäevale (25. juu- 
lil / 7. augustil). Mõlemad päevad on seotud eelkõige ilmaennustamisega (NARODNÕJE PRIMETõ). Eestis on lambapühana tuntud suvine annepäev, mille kiriklik taust on sedavõrd kahanenud, et päev ise on nihkunud 26. juulile (Kõiva 2004).

${ }^{41}$ Toimetuse kommentaar: Serbia keelt kirjutatakse tänapäeval nii kirillitsas kui ka ladina tähestikus.

42 Toimetuse kommentaar: Õigeusklikel varem ohvritoiduna, peie- ja mälestussöömaaegade menüüsse kuulunud nisu, granaatõuna jm seemnetest, pähklitest, rosinatest jms segatud roog (kreeka keeles koliva, kollyva, serbia keeles koljiva, kirillitsas kirjutatuna $\kappa о љ и \ell o$, rumeenia keeles colivă), millest on kujunenud jõuluaja toit. Toidu keskele võidakse asetada küünal. Mõningates paikades on see tuntud ka oma algse nimetuse panspermia järgi - niisugust nimetust kandis selline segu Vanas Kreekas, kus seda ohverdati Demeterile ja teistele jumalatele viljakuse suurendamiseks, surnute hingedele ja Dionysose auks (WIKIPEDIA).

43 Toimetuse kommentaar: Atanasiusepäevi (vene traditsioonis afanassipäev) on õigeusu kalendris kolm: kevadine (2./15. mai), suvine (5./18. juuli) ja talvine (18./31. jaanuar). Kevadine ja talvine atanasiusepäev on seotud Aleksandria Atanasiuse ehk Atanasius Suurega, kes sündis 295. aasta paiku. 319. aastal sai temast diakon, kes 325. aastal osales peapiiskopi saatjana Nikaia I oikumeenilisel kirikukogul, kus võttis julgelt sõna arianismi (4.-7. sajandi usuvool, mis väitis, et Kristus pole jumalik ega igavene) vastu. Sai 328. aastal Aleksandria peapiiskopiks, seega Egiptuse kirikupeaks. Järgneva 38 aasta jooksul pagendasid arianistid teda korduvalt, kuid ikka kutsuti ta tagasi. Alles 366. aastast sai ta segamatult oma piiskopkonnas tegutseda. Suri 2. mail 373 Aleksandrias. Arianistide vastaseid on nimetatud ka atanasistideks. Läänekirikus tähistatakse tema surma-aastapäeva 2./15. mail, õigeusu kirikus on tal kaks mälestuspäeva - nii 2. mail kui ka 18./31. jaanuaril (ÖKUMENISCHEs HeILigeNLEXIKon; GLaubenszeugen).

Suvine atanasiusepäev on aga seotud hoopis Áthose Atanasiusega, kes sündis praeguse Türgi alal Trabzonis ja kandis algul nime Abraham. Atanasiose nime sai ta alles Bitüünia kloostris. Kloostriülema soovitusel siirdus ta sealt eksiili, jõudes juba 885. aastal keiser Basileos I poolt pühaks mäeks kuulutatud Áthosele, kuhu ta rajas 963. aastaks kloostri. 970. aastal koostas ta Püha Maa esimeste kloostrite eeskujul jumalateenistuste korra. Tema rajatud klooster on tänini Áthose suurim ja kannab nime Megisti Lawra (Glaubenszeugen). Athose Atanasiuse mälestuspäeva 5./18. juulil tähistab üksnes idakirik.

Vene rahvakalendris on kõigil neil päevadel oma roll. Kevadine afanassipäev, mis langeb kokku kevadise borisi- ja glebipäevaga (Борис и Глеб Сеятели 'Boriss ja Gleb Külvajad'), kannab ka analoogset nime - Афанасий-звсевалник 'Afanassi-Külvaja', tähistades külvi- ja ööbikulauluaja algust. Suvine afanassipäev aitas ennustada algava koristusaja viljasaaki ja ilma. Talvine afanassipäev kannab nime Афанасий Лолонос'Afanassi Ninanäpistaja), sest see jääb suurte jaanuaripakaste aega (NARODNÕJE PRIMETÕ).

44 Toimetuse kommentaar: Maaslenits (vene keeles ıасленица) ehk võinädal, kevadiste liikuvate pühade esimene nädal, kaheksa nädalat enne lihavõtteid. Tinglikult kuuluvad sellesse tsüklisse viimsekohtu lihast loobumise pühapäev võinädala eel ning andestamise ja piimast loobumise pühapäev vahetult enne seitse nädalat kestvat lihavõttepaastu ehk suurt paastu (Mordva RAHVAKALENDER). See on iidse taustaga püha, muinasslaavi uusaasta. Võinädal algab esmaspäeval avapidustustega, neljapäev on aga eriti suur pidupäev, nn suur maaslenits (цирокая ласлениц). Sellel päeval riietutakse vastassoo rõivastesse, kantakse maske ja veidraid kostüüme. Või- 
nädalasse kuuluvad saanisõit, liulaskmine, aga ka mitmesugused nn jõu- ja osavusmängud jpm - see on viimane lõbutsemine enne pikka paastuaega. Juba võinädalal on lihasöömine keelatud, kuid piim ja munad veel lubatud. Kogu nädala jooksul käib usin pliinide küpsetamine ja söömine. Ülisuurtes anumates valmistatavasse pliinitainasse pannakse ohtralt mune ja sulatatud võid, pliinide juurde pakutakse suhkrut ja keedist, musta ja punast kalamarja, hapukoort, sulatatud võid, kala ja sibulat (Suitso 2006). Eestis tähistatakse Setumaal. Traditsiooniliselt sel nädalal tööd ei tehtud. Peetakse paabapraasnikut - naistepidu, mis on alati neljapäevasel päeval. Mujal Eestis on võinädala vasteks vastlad, mis varematel aegadel oli samuti mitmepäevane ja rohkete lõbustustega püha.

45 Toimetuse kommentaar: Paganliku taustaga püha, teine teisipäev pärast lihavõttenädalat - vanemate mälestuspäev, surnuaiapüha (vene k paдyнuиa), setu traditsioonis raadovits - hingedepäev, rõõmukuulutamine surnutele, teine teisipäev pärast lihavõttenädalat.

46 Toimetuse kommentaar: Palmipuudepüha ehk urbepäev, Jeesuse Jeruusalemma minemise päev - liikuv püha, pühapäev enne kannatusnädalat, nii vene kui ka eesti rahvakalendris on sellel päeval tavaks tuua tuppa urbadega pajuoksi ja urbida.

\section{Arhiiviallikad}

$\mathrm{AA}=$ autori arhiiv (= Irina Sedakova isiklik arhiiv).

\section{Kirjandus}

Ben-Amos, Dan 1969. Analytical Categories and Ethnic Genres. Genre 2: 3, lk 275301.

Dal 1955 = Даль, Владимир. Толковый словарь живого великоруссково языка I-IV. Москва: Государственное издательство иностранных и национальных словарей (http://vidahl.agava.ru/ - 20. september 2006).

Ikonomov 1968 = Икономов, Николай И. et al. (toim). Балканска народна мъдрост: Успоредици на български, сръбски, турски, рульнски, гръщки и албански пословици и поговорки. София: Изд. на БАН.

Korinfski 1994 (1901) = Коринфский, Аполлон А. Народная Русь: Кругльий вод сказаний, поверий, обычаев и пословии русского народа. Клуб любителей истории Отечества. Москва: Московский рабочий (ümbertrükk: Москва: Клюкин 1901) (vt ka http:// www.booksite.ru/fulltext/kor/inp/hsky/index.htm - 20. september 2006).

Permjakov 1970 = Пермяков, Григорий Л. От поговорки до сказки: Залетки по общей теории клище. Исследования по фольклору и мифологии Востока. Москва: Наука.

Polištšuk \& Ponomarjov 2000 = Полищук, Н. С. \& Пономарев, Анатолий П. et al . (toim). Украиниы. Народы и культуры 3. Москва: Наука. 
Propp 1963 = Пропп, Владимир Я. Русккие аграрнье праздики: Опьы историкоэтнографического исследования. Ленинград: Издательство Ленинградского университета.

Sedakova, Irina \& Tolstaja, Svetlana 1995. Афанасий (St. Athanasius). Толстой, Никита И. (toim). Славянские дребности: Этнолинвистический словарь 1. Москва: Международные отношения, lk 119-121.

Sedakova, Irina 2001. Politics and Folk Religion in the Period of Transition. Acta Ethnographica Hungarica 46: 1-2, lk 131-136.

Slavejkov 1972 = Славейков, Петко Р. Бъларски притчи или пословици и характерни дули. София: Български писател.

Snegirev 1999 = Снегирев, Иван М. Русские народные пословицы и притчи. Традиционная духовная культура славян. Издание памятников. Москва: Индрик.

Stojnev 1994 = Стойнев, Анани Б. (toim). Бъларска митология: Енциклопедичен речник. София: Издателска група 7М + Логис.

Tolstaja 2005 = Толстая, Светлана М. Іолеский народный календарь. Традиционная духовная культура славян: Современные исследования. Москва: Индрик.

Tolstaja, Svetlana 2001 [ilmus 2005]. Rites for Provoking and Stopping Rain in Slavonic Folk Tradition. Cosmos 17, lk 179-195.

Tolstoi, Nikita I. 2002 [ilmus 2005]. The Magic Circle of Time. Cosmos 18, lk 193-206.

Tšitšerov 1957 = Чичеров, Владимир И. Зилиий период русского зелледельческого календаряXVI-XIX веков: Очерки по истории народньх верований. Труды Института этнографии им. Н. Н. Миклухо-Маклая: Новая Серия 40. Москва: Издательство Академии наук СССР.

Vostrikov 2000 = Востриков, Олег В. Традиционная культура Урала: Oпыт этноидеографического словаря русских гоһоров Свердловской области 1: Народньй календарь. Екатеринбург: Уралское литературное агентство.

\section{Kommentaaride koostamisel kasutatud kirjandus}

Antiigileksikon 1985. Irmscher, Johannes \& Johne, Renate (koost). Tallinn: Valgus.

Catholic Encyclopedia. New Advent (http://www.newadvent.org/cathen/index.html 12. september 2006).

Eesti-vene õigeusu seletav sõnastik. Moskva Patraiarhaadi Eesti Õigeusu Kirik: Ametlik kodulehekülg (http://www.orthodox.ee/sonastik.php?d=sl - 12. september 2006)

EV = Hussar, Anne \& Krikmann, Arvo \& Sarv, Ingrid 1984. Vanasõnaraamat. Tallinn: Eesti Raamat (http://www.folklore.ee/ kriku/VSR/FRAMEST.HTM - 12. september 2006).

Glaubenszeugen: Oekumenischer Kalender (http://www.glaubenszeugen.de/ - 12. september 2006). 
Hronos = Румянцев, Вячеслав (toim). Хронос - вселирная история 6 интернете (http:// www.hrono.ru/ - 12. september 2006).

Narodnõi kalendar = Народный календарь “Зила" (http://kalendar.home.nov.ru/index. htm - 12. september 2006).

Kadžaja 2006 = Каджая, Валерий. За 9 месяцев до Рождества. Русский Курьер 13 (546), 3. aprill (http://www.ruscourier.ru/archive.php?id=1212 - 12. september 2006).

Kõiva, Mare 2004. Rahvakalendri tähtpäevad. Kõiva, Mare \& Särg, Taive \& Vesik, Liisa (koost). Berta: Eesti rahvakalendri tähtpäevade andmebaas (http://www.folklore. ee/Berta/kalender.php - 12. september 2006).

Mordva rahvakalender = Hiiemäe, Mall. Mordva rahvakalender (http://www.folklore. ee/rl/folkte/sugri/mordva/rk/ - 12. september 2006)

Narodnõje primetõ = Народные прилеть и суеһерия: Календарь народных прилет (http://primeti.chat.ru - 12. september 2006).

Piirissaare kogudus. Karu, Katrin (toim). Vene Vanausulised Eestis (http://www. starover.ee/est/kirikud/piirisaar.html - 12. september 2006)

Pravoslavnõi kalendar 2006 = ІІравославный календарь 2006 (http://days.pravoslavie.ru/ - 12. september 2006).

Ritual.ru: Инфорлационньй портал ритуальньх услуд (http://ritual.su/texts/traditions/ russian.html - 12. september 2006).

Saints \& Angels. Catholic Online (http://www.catholic.org/saints/ - 12. september 2006).

Setukaisten ystävät-yhdistys. Setukaisten ystävät (http://www.setu.info/setu1_99.html - 12. september 2006)

Shilov, Valery. St Martyrs Florus and Laurus (The Miracle of the Archangel Michael). M\&M Art Ltd (http://www.mmartltd.com/galleryimage.asp?iid=303 - 12. september 2006).

Suitso, Maire 2006. Lihavõtted: legend, kombestik ja sümbolid. DELFI Naisteleht, 13. aprill (http://woman.delfi.ee/varia/huvitav_teada/article.php?id=12660670 -12. september 2006).

Vikipeedia: Vaba entsüklopeedia (http://et.wikipedia.org/wiki - 12. september 2006).

Wikipedia: The Free Encycklopedia (http://en.wikipedia.org/wiki - 12. september 2006).

Wf-f 2006 = Women for Faith \& Family (http://www.wf-f.org/index.html -12. september 2006).

Õigeusu kiriku pühadekalender (www.maria-magdaleena.ee/Oigeusu_kiriku_pyhad. doc -12 . september 2006).

Ökumenisches Heiligenlexikon (http://www.heiligenlexikon.de - 12. september 2006). 


\title{
Summary
}

\section{The Ritual Year as Reflected in Proverbs: General Notes}

\author{
Irina Sedakova
}

Key words: calendar prediction, folk calendar, ritual year, proverbs, Orthodox calendar

The article discusses expressions of folk wisdom which allude to the concept of time, the system structured according to the calendar and the rituals, performed on certain dates. The yearly cycle has developed a system of folk aphorisms concerning almost every day in the calendar and covering all the activities of the man and of the nature in great detail. Terms like aphorisms, proverbs, sayings, etc. are used to denote various folklore (speech) genres depicting the ritual year in a rather provisional manner. Apart from the genres mentioned, idioms, comparisons and some spells and curses are also examined.These speech folklore genres are a vast field of research. The question of whether we can speak of ethnic paremia, as asked by the prominent folklorist Dan Ben-Amos (1969) and supported by other scholars, is still very topical, especially in view of the type of proverbial sayings under discussion. The main issues that are examined in the paper are: what is universal and what is unique. The article mainly focuses on sayings which concern the ritual year and outlines the specific features of the folk perception of time as reflected in the calendar. Folk aphorisms reflect the ritual year through names of holidays, terms of ritual objects, food and participants, and through allusions to certain celebration throughout the year. The paremia can express direct meaning, appropriate for only one situation, or they can be of metaphorical nature, describing a set of situation.

Each European culture has developed its own ways of seeing the ritual year through metaphorical proverbs, idioms and sayings. Although the set of holidays chosen by each folk paremiological tradition may be different, unique even, the major principles of mentioning a rite in a proverb have universal value and correspond to the structural and semiotic rules of the folklore genre. 